Prepared in cooperation with the Mobile Area Water and Sewer System

Hydrogeologic Conditions and a Firm-Yield Assessment for J.B. Converse Lake, Mobile County, Alabama, 1991-2006

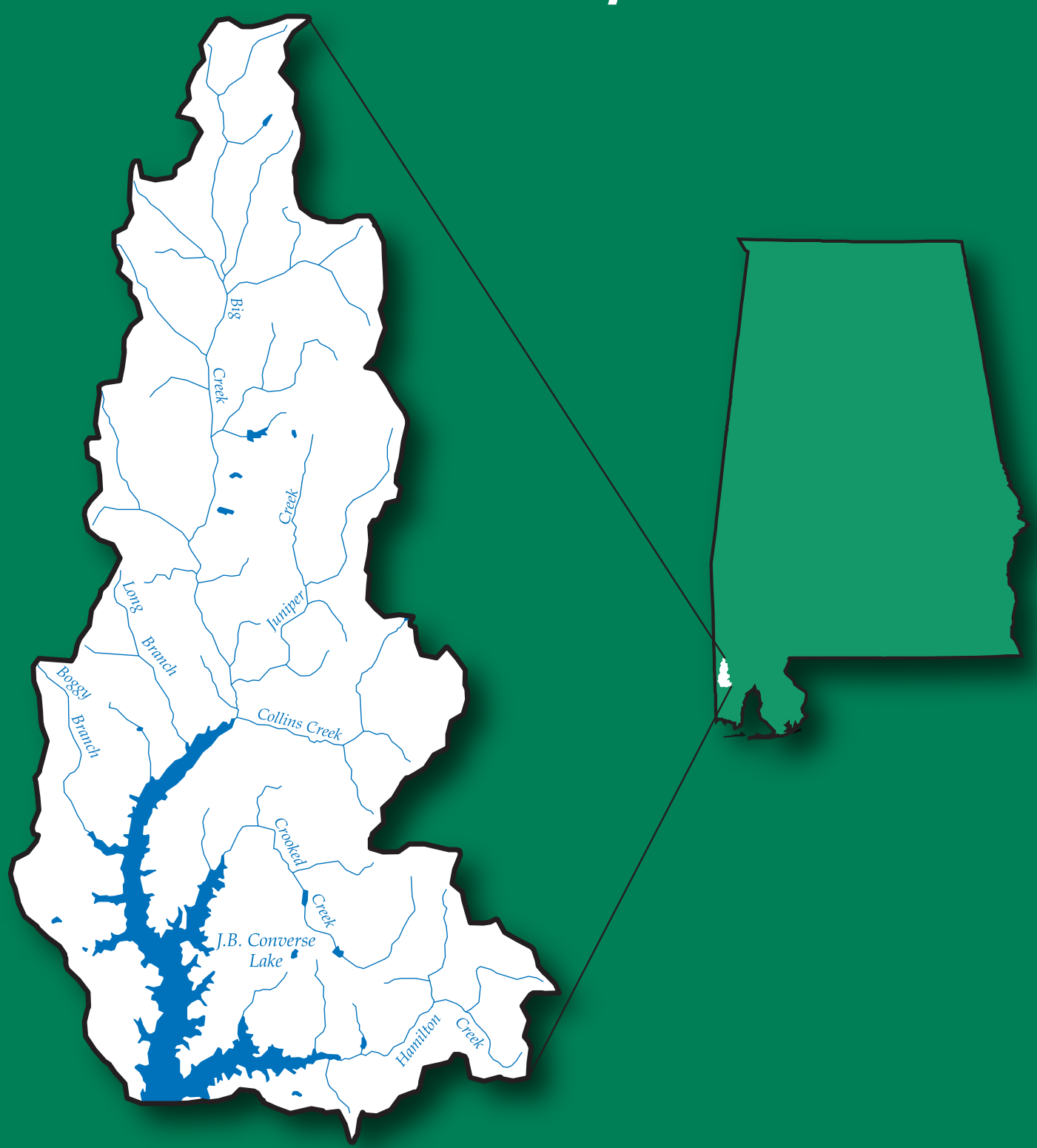

Scientific Investigations Report 2008-5005, Second Edition—February 2009 
Cover illustration: Map showing location of J.B. Converse Lake, Alabama (see figure 1). 


\section{Hydrogeologic Conditions and a Firm-Yield Assessment for J.B. Converse Lake, Mobile County, Alabama, 1991-2006}

By Carl S. Carlson and Stacey A. Archfield

Prepared in cooperation with the Mobile Area Water and Sewer System

Scientific Investigations Report 2008-5005, Second Edition—February 2009 


\section{U.S. Department of the Interior DIRK KEMPTHORNE, Secretary}

\section{U.S. Geological Survey \\ Mark D. Myers, Director}

\section{U.S. Geological Survey, Reston, Virginia: 2009}

For product and ordering information:

World Wide Web: http://www.usgs.gov/pubprod

Telephone: 1-888-ASK-USGS

For more information on the USGS — the Federal source for science about the Earth, its natural and living resources, natural hazards, and the environment:

World Wide Web: http://www.usgs.gov/

Telephone: 1-888-ASK-USGS

Any use of trade, product, or firm names is for descriptive purposes only and does not imply endorsement by the U.S. Government.

Although this report is in the public domain, permission must be secured from the individual copyright owners to reproduce any copyrighted materials contained within this report.

Suggested citation:

Carlson, C.S., and Archfield, S.A., 2009, Hydrogeologic conditions and a firm-yield assessment for J.B. Converse Lake, Mobile County, Alabama, 1991-2006: U.S. Geological Survey Scientific Investigations Report 2008-5005, Second Edition-February 2009, 21 p. 


\section{Contents}

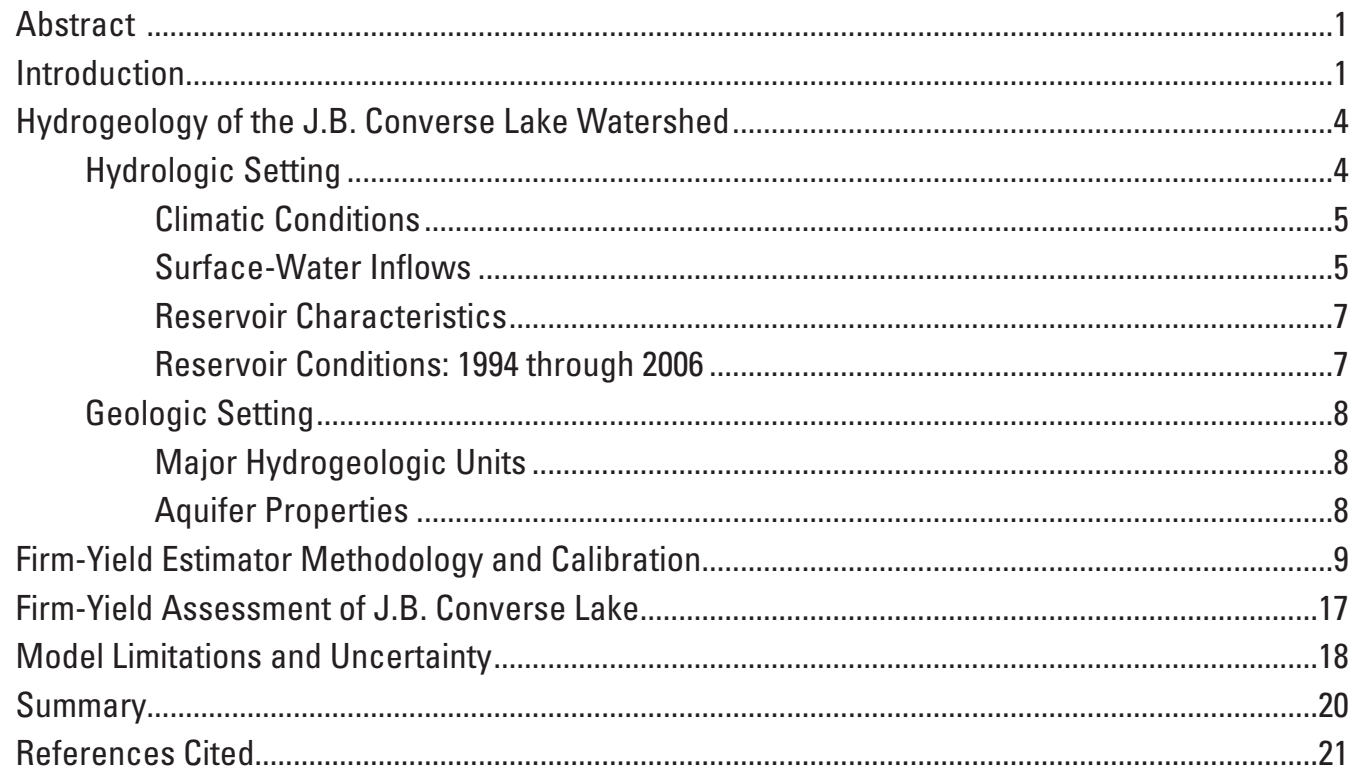

\section{Figures}

1. Map showing locations of three continuous (1991-2006) and four short-term (1991 or 1991-92) streamflow data-collection sites in the J.B. Converse Lake

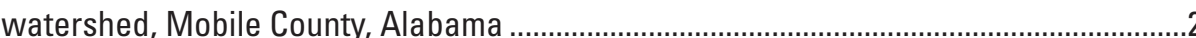

2. Diagram showing possible sources and losses of water for a hypothetical drinking-water reservoir in contact with a sand and gravel aquifer

3. Map showing underlying geologic units and the locations of seven gaged subwatersheds, and a smaller, ungaged watershed that compose the total J.B. Converse Lake watershed, Mobile County, Alabama.

4-7. Graphs showing-

4. Monthly precipitation for 1991 through 2006 recorded at the National Weather Service station, Mobile airport, Alabama, in relation to normal monthly precipitation at this station for the period of record 1971-2000.....

5. Mean monthly pan evaporation data obtained from the National Weather Service station at Mobile airport and converted to free-surface evaporation using evaporation coefficients from Farnsworth and others (1982) ......6

6. Coefficients of relations of reservoir surface area to storage and reservoir stage to storage for J.B. Converse Lake and for use in the firm-yield estimator

7. Average withdrawals from J.B. Converse Lake in Alabama for public supply, in million gallons per day, for the period 1990 through 2006

8. Diagrams showing reservoir water level at equilibrium with the water table in the surrounding aquifer, response of the water table to a decrease in the water level of the reservoir relative to the water table, and an increase in the water level of the reservoir relative to the water table. 
9. Graphs showing factors used in the firm-yield estimator to represent monthly demand for the period 1991-2006 calculated as total withdrawals by month divided by the average withdrawal for the corresponding year and the average demand for the period 1991-2006 for J.B. Converse Lake in Alabama.

10. Map showing variables that represent the distance from the reservoir shoreline to the aquifer boundary, $a$, and the length of the reservoir shoreline in contact with the aquifer, $L$, used for the ground-water exchange component of firm yield for a reservoir in contact with a sand and gravel aquifer, J.B. Converse Lake, Alabama

11. Graphs showing simulated and measured reservoir water levels for drought-year 2000 and the period 1991 through 2006 for model calibration simulations run to match the lowest measured drought-year 2000 water level $(101.7 \mathrm{ft})$ to estimate aquifer transmissivity for J.B. Converse Lake, Alabama

12. Graphs showing total measured monthly precipitation and estimated usable reservoir storage for the period 1991-2006 for each average daily firm-yield estimate of 79 million gallons per day and 83 million gallons per day for J.B. Converse Lake, Alabama

\section{Tables}

1. Streamflow conditions for the 1991-2006 water years in selected tributaries to J.B. Converse Lake, Alabama.

2. Aquifer transmissivities calculated by using the Prudic (1991) equation and specific-capacity data and aquifer-storage coefficients for each of 10 wells in the area of J.B. Converse Lake, Alabama.

3. Non-unique combinations of input values for transmissivity (T), aquifer storage $(S)$, aquifer width $(a)$, and length of shoreline in contact with the aquifer $(L)$ that matched the lowest measured water level (101.7 feet in drought-year 2000) for model-calibration simulations to determine a reasonable value for aquifer transmissivity, using the withdrawal rate of 74.13 million gallons per day in 2000 .

4. Estimates of average daily firm yield for J.B. Converse Lake, Alabama, calculated with total surface-water flow and ground-water exchange with the reservoir using results of the firm-yield estimator model-calibration process and sensitivity analysis and values from table 2 for various values of transmissivity (T), aquifer storage (S), aquifer width (a), and length of shoreline in contact with the aquifer $(L)$ 


\section{Conversion Factors and Abbreviations}

\begin{tabular}{|c|c|c|}
\hline Multiply & By & To obtain \\
\hline \multicolumn{3}{|c|}{ Length } \\
\hline inch (in.) & 2.54 & centimeter $(\mathrm{cm})$ \\
\hline inch (in.) & 25.4 & millimeter $(\mathrm{mm})$ \\
\hline foot $(\mathrm{ft})$ & 0.3048 & meter $(\mathrm{m})$ \\
\hline mile (mi) & 1.609 & kilometer $(\mathrm{km})$ \\
\hline \multicolumn{3}{|c|}{ Area } \\
\hline acre & 4,047 & square meter $\left(\mathrm{m}^{2}\right)$ \\
\hline square mile $\left(\mathrm{mi}^{2}\right)$ & 2.590 & square kilometer $\left(\mathrm{km}^{2}\right)$ \\
\hline \multicolumn{3}{|c|}{ Volume } \\
\hline gallon (gal) & 3.785 & liter $(\mathrm{L})$ \\
\hline million gallons (Mgal) & 3,785 & cubic meter $\left(\mathrm{m}^{3}\right)$ \\
\hline cubic foot $\left(\mathrm{ft}^{3}\right)$ & 0.02832 & cubic meter $\left(\mathrm{m}^{3}\right)$ \\
\hline cubic mile $\left(\mathrm{mi}^{3}\right)$ & 4.168 & cubic kilometer $\left(\mathrm{km}^{3}\right)$ \\
\hline acre-foot (acre-ft) & 1,233 & cubic meter $\left(\mathrm{m}^{3}\right)$ \\
\hline \multicolumn{3}{|c|}{ Flow rate } \\
\hline foot per day (ft/d) & 0.3048 & meter per day $(\mathrm{m} / \mathrm{d})$ \\
\hline cubic foot per second $\left(\mathrm{ft}^{3} / \mathrm{s}\right)$ & 0.02832 & cubic meter per second $\left(\mathrm{m}^{3} / \mathrm{s}\right)$ \\
\hline gallon per day (gal/d) & 0.003785 & cubic meter per day $\left(\mathrm{m}^{3} / \mathrm{d}\right)$ \\
\hline million gallons per day (Mgal/d) & 0.04381 & cubic meter per second $\left(\mathrm{m}^{3} / \mathrm{s}\right)$ \\
\hline \multicolumn{3}{|c|}{ Transmissivity* } \\
\hline foot squared per day $\left(\mathrm{ft}^{2} / \mathrm{d}\right)$ & 0.09290 & meter squared per day $\left(\mathrm{m}^{2} / \mathrm{d}\right)$ \\
\hline
\end{tabular}

Vertical coordinate information is referenced to the North American Vertical Datum of 1929 (NGVD 29).

Horizontal coordinate information is referenced to the North American Datum of 1983 (NAD 83).

Elevation, as used in this report, refers to distance above the vertical datum.

*Transmissivity: The standard unit for transmissivity is cubic foot per day per square foot times foot of aquifer thickness [(f $\left.\left.\mathrm{ft}^{3} / \mathrm{d}\right) / \mathrm{ft}^{2}\right] \mathrm{ft}$. In this report, the mathematically reduced form, foot squared per day $\left(\mathrm{ft}^{2} / \mathrm{d}\right)$, is used for convenience.

\section{Abbreviations}

a

FYE

GIS

L

MassDEP

MAWSS

Mgal

NWIS

$S$

$T$

USGS
Average distance from reservoir shoreline to aquifer boundary

Firm-yield estimator

Geographic Information System

Length of reservoir shoreline in contact with the aquifer

Massachusetts Department of Environmental Protection

Mobile Area Water and Sewer System

Million gallons

National Water Information System

Aquifer storage value

Aquifer transmissivity value

U.S. Geological Survey 



\title{
Hydrogeologic Conditions and a Firm-Yield Assessment for J.B. Converse Lake, Mobile County, Alabama, 1991-2006
}

\author{
By Carl S. Carlson and Stacey A. Archfield
}

\section{Abstract}

J.B. Converse (Converse) Lake is the primary source of drinking water for the City of Mobile, Alabama. Concerns regarding the ability of the reservoir to meet current and future water demands during drought conditions have prompted this study. The 1991 through 2006 water years ${ }^{1}$ included a drought that occurred during 2000, and drought conditions currently (2007) are affecting the area. To assist officials of the Mobile Area Water and Sewer System in planning for future demands for drinking water in the Mobile metropolitan area, the firm yield for Converse Lake was estimated by the U.S. Geological Survey.

The firm yield of Converse Lake was estimated using the Massachusetts Department of Environmental Protection's firm-yield-estimator (FYE) model, which recently was refined by the U.S. Geological Survey. The model uses a mass-balance approach to determine the maximum average daily withdrawal rate that can be sustained during a period of record that includes a drought of record. If the reservoir is in contact with an aquifer, the FYE also includes routines that estimate the volume of ground-water and surface-water exchange between the aquifer and the reservoir.

The average daily firm yield for Converse Lake was estimated to be 79 million gallons per day using the FYE routine that does not include ground-water exchange between the reservoir and the adjacent aquifer. Observed lake levels and withdrawals during the drought of 2000 indicate that more than 74 million gallons per day of water were withdrawn without complete depletion of reservoir storage. Therefore, it is likely that ground-water exchange with the reservoir may supplement available reservoir storage. If water exchange occurs between the aquifer and the reservoir, an increase in the volume of water available to the reservoir may occur during a drought. To quantify the potential ground-water contribution to reservoir storage, an analytical solution was applied to the FYE simulation of Converse Lake to estimate groundwater exchange between the reservoir and the aquifer. Aquifer

\footnotetext{
${ }^{1}$ Water year is the period October 1 through September 30 and is identified by the year in which the period ends. For example, the 1991 water year began on October 1, 1990, and ended on September 30, 1991.
}

properties required by the FYE were estimated by model calibration to observed water levels that occurred during the drought of 2000. When ground-water exchange between the reservoir and adjacent aquifer is included, the average daily firm yield increased to 83 million gallons per day.

The estimate of 83 million gallons per day incorporates both total surface-water flow and ground-water exchange components. This analysis indicated that direct ground-water interaction contributes about 5 percent of the firm yield of Converse Lake. However, the average daily firm yield of 83 million gallons per day, based in part on calibrated values for aquifer transmissivity and storage, can be used only as a guideline until these aquifer properties can be defined better by field investigation in the Converse Lake watershed.

\section{Introduction}

J.B. Converse Lake, hereafter referred to as Converse Lake, is a 3,600-acre tributary-storage reservoir in Mobile County in southwestern Alabama (fig. 1). The lake is the primary source of drinking water for the Mobile area and a popular recreational area for fishing and boating. The watershed is largely rural, but residential and commercial development is expanding westward from the City of Mobile (Journey and Gill, 2001).

The Mobile Area Water and Sewer System (MAWSS) manages Converse Lake and the E. Morgan Stickney and Harry E. Myers Water Filtration Facilities. These two facilities treat raw water withdrawn by a pumping station on Converse Lake (fig. 1) and deliver the treated water to the City of Mobile. As demands for public drinking water are likely to increase in the future, the maximum withdrawal rate of water from the reservoir during severe drought conditions needs to be determined.

The amount of water available for withdrawal from a water-supply reservoir depends on the water balance of the reservoir. Most reservoirs accumulate water from surface- and ground-water inflows and from precipitation on the reservoir surface; outflows occur by evaporation from the reservoir surface, water-supply withdrawals, and controlled and uncontrolled releases (fig. 2; Waldron and Archfield, 2006). 


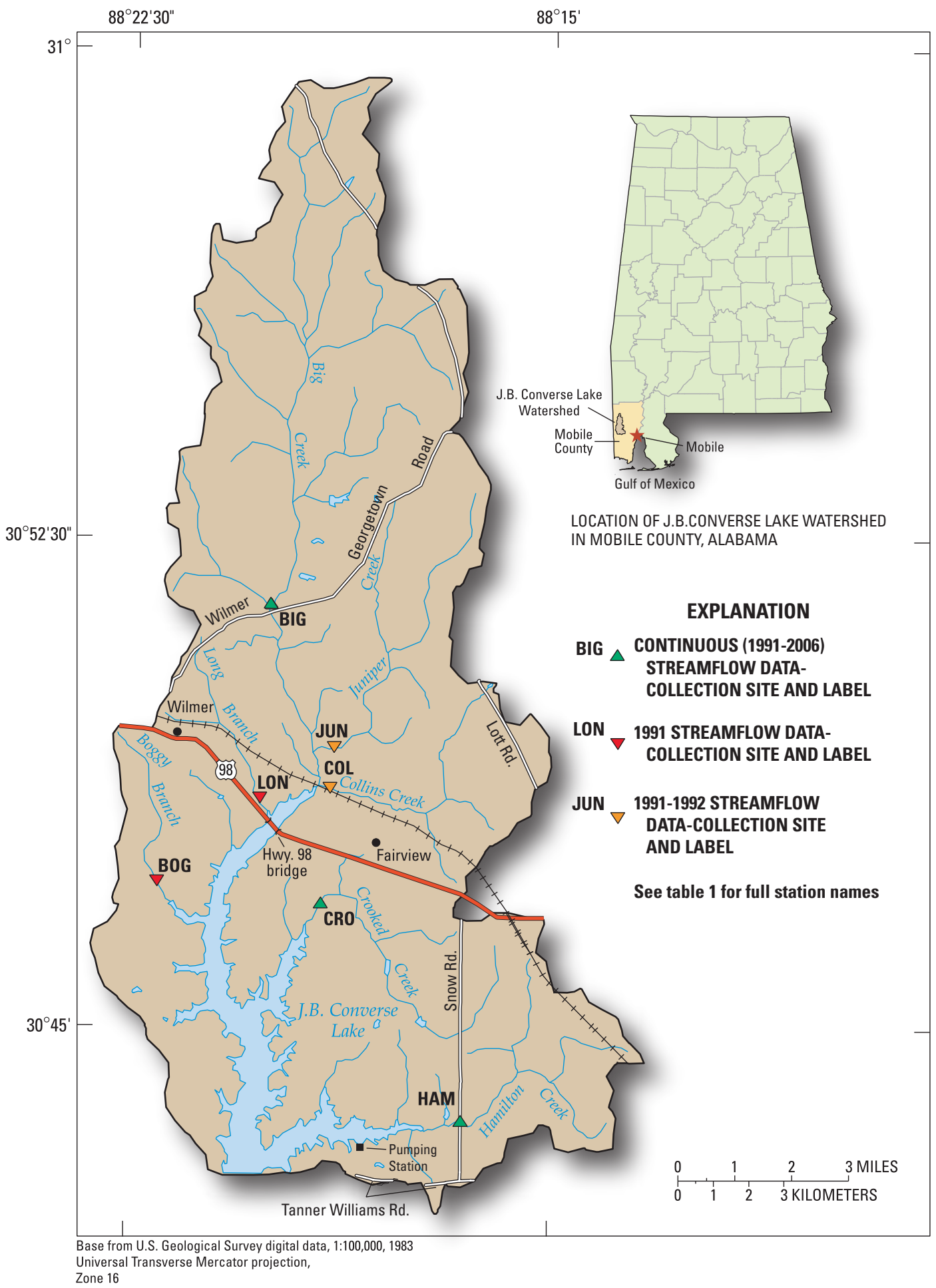

Figure 1. Locations of three continuous (1991-2006) and four short-term (1991 or 1991-92) streamflow data-collection sites in the J.B. Converse Lake watershed, Mobile County, Alabama. 


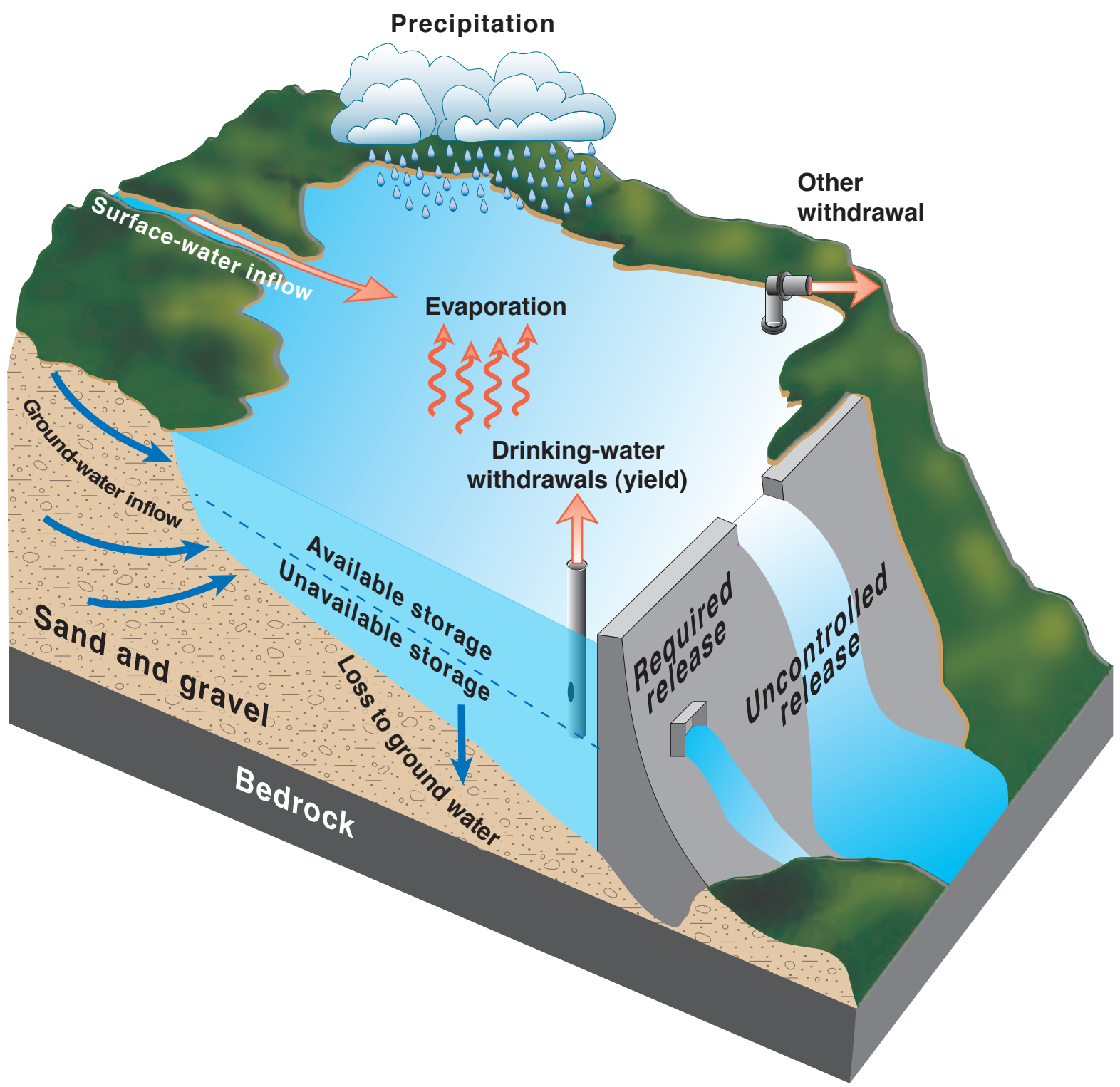

Figure 2. Possible sources and losses of water for a hypothetical drinking-water reservoir in contact with a sand and gravel aquifer (Waldron and Archfield, 2006).

Future water-supply demands could increase the likelihood that withdrawals may deplete available reservoir-storage capacity and result in supply shortfalls. Current water-supply demands may be met under normal climatic conditions, but a severe drought may reduce the reservoir's current yield. Therefore, the reservoir's response to drought conditions needs to be evaluated. A common way to evaluate reservoir response is by estimating the firm yield, which is the maximum yield of a reservoir under drought conditions, without completely depleting available reservoir storage (Waldron and Archfield, 2006). Withdrawals from a reservoir that are equal to or less than the firm yield ensure that the reservoir will meet water-supply demands, assuming that long-term climatic and hydrologic conditions remain stationary. As future demands for water supply increase, estimation of the firm yield provides an upper limit that can be compared to future demands to determine if the reservoir will be able to meet those additional demands in excess of current withdrawals. Alternatively, the firm yield can be compared to current reservoir withdrawals to determine if the withdrawals can be sustained through a drought (Archfield and Carlson, 2006). In response to likely increases in future water demand, the firm yield of Converse Lake was estimated by the U.S. Geological Survey (USGS), in cooperation with the Mobile Area Water and Sewer System (MAWSS), using the firm-yield estimator (FYE) (Archfield and Carlson, 2006; Waldron and Archfield, 2006). 
This report describes the hydrogeologic conditions of the Converse Lake watershed; the development, calibration, and limitations of the FYE relative to the Converse Lake watershed; and average daily firm-yield estimates for Converse Lake with and without groundwater exchange between the aquifer and the reservoir. The simulation period for this analysis was 1991 through 2006, which included the drought of 2000. The FYE provides an estimate of the upper limit for the rate of withdrawal that can be pumped from the reservoir during a drought similar to the drought that occurred during 2000 without depleting available reservoir storage.

\section{Hydrogeology of the J.B. Converse Lake Watershed}

The Converse Lake watershed is west of the City of Mobile near the Alabama State line (fig. 1). Converse Lake, previously known as Big Creek Lake, was formed from the impoundment of Big Creek in 1952. Two geologic units consisting of semiconsolidated sand, silt, gravel, and clay underlie the Converse Lake watershed (fig. 3).

\section{Hydrologic Setting}

Most reservoirs accumulate water from precipitation on the reservoir surface and from surface- and groundwater inflows; outflows occur by evaporation from the reservoir surface, watersupply withdrawals, and controlled and uncontrolled releases. The USGS collected streamflow data on seven major streams contributing flow to Converse Lake. Other data collected for the period July 1990 through September 2006 consisted of monthly precipitation and monthly pumpage from the reservoir. Further data included average monthly evaporation rates, reservoir volume and area characteristics, and estimates of aquifer properties. These data were used in the FYE to estimate average daily firm yield for Converse Lake.

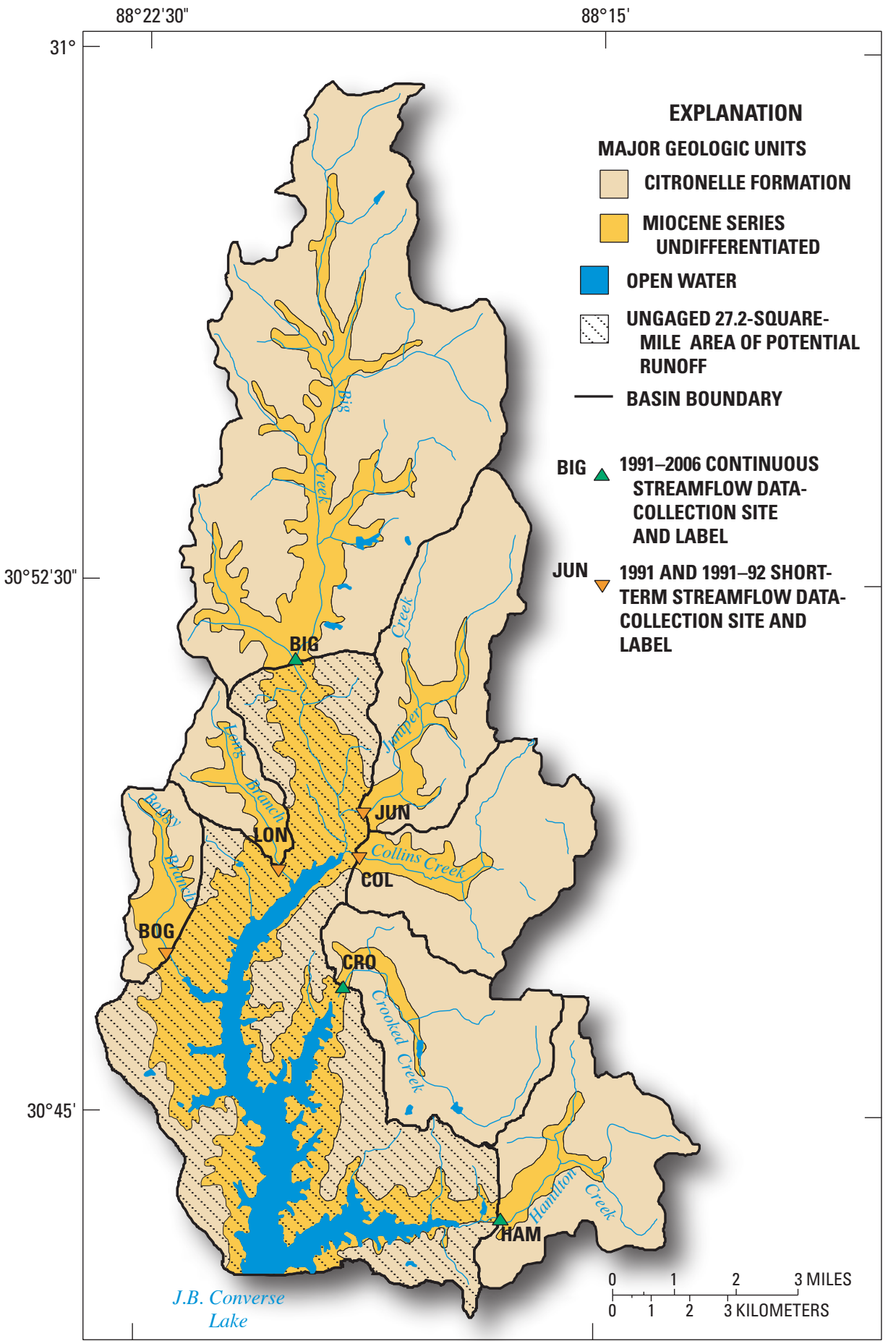

Figure 3. Underlying geologic units and the locations of seven gaged subwatersheds, and a smaller, ungaged watershed that compose the total J.B. Converse Lake watershed, Mobile County, Alabama. 


\section{Climatic Conditions}

The climate of the Converse Lake watershed is subtropical. Precipitation occurs almost exclusively as rainfall. Several types of weather patterns influence the climate. The Gulf of Mexico produces warm, humid air masses that move inland and provide precipitation in the form of episodic thunderstorms. Extremely high-intensity rainfall is produced from large tropical storms that enter the Gulf of Mexico and move inland in late summer and early fall (July to September). In winter, the climate is further influenced by arctic fronts that move south from the Midwest and contribute more continuous precipitation and cooler temperatures (Journey and Gill, 2001).

Precipitation data from the National Weather Service station at Mobile airport were used in this study (fig. 4). The average annual precipitation in the Converse Lake area for the period 1991 through 2006 was 67 inches (in.) and ranged from 46 in. in year 2000 to 87 in. in 1998 (National Oceanic and Atmospheric Administration, 2007). Average monthly precipitation during this period ranged from $3.7 \mathrm{in}$. in October to about 7.5 in. in July. Monthly precipitation exceeded 10 in. for several months during the 1991-2006 period. During the period 1961 to 1990 , the lowest average annual precipitation was 44 in. (Journey and Gill, 2001), which is similar to the lowest average annual value of $46 \mathrm{in}$. that occurred in year 2000 during this study. Therefore, the observed drought during year 2000 represents the drought of record for the purposes of this analysis.

Average monthly pan evaporation data were obtained from the National Weather Service station at Mobile airport (Farnsworth and Thompson, 1982). Pan evaporation data were converted to free-surface evaporation using evaporation coefficients from Farnsworth and others (1982) for input to the FYE (fig. 5).

\section{Surface-Water Inflows}

Streamflow data were collected continuously from 1991 through 2006 on three streams (Big Creek, Crooked Creek, and Hamilton Creek) in the Converse Lake watershed (table 1). Short-term continuous streamflow data were collected for 1991 at Boggy Branch and Long Branch and for 1991-1992 at Collins Creek and Juniper Creek (fig. 1; table 1).

The seven major gaged streams, covering an area of 71.6 square miles $\left(\mathrm{mi}^{2}\right)$ of the total Converse Lake watershed area of $104.4 \mathrm{mi}^{2}$, contribute flow to Converse Lake (fig. 3). During the 1991 through 2006 water years, the greatest measured inflows to the reservoir were from Big Creek, Crooked Creek, and Hamilton Creek with average surfacewater flows of 62.0, 17.2, and 22.4 cubic feet per second $\left(\mathrm{ft}^{3} / \mathrm{s}\right)$, respectively (table 1$)$. Streamflow records for the period 1991 through 2006 for the three continuous streamflow datacollection sites were used to extend the record for the four short-term sites. The daily streamflow data were aggregated to determine total monthly surface-water flows to Converse Lake.

Streamflows on Boggy Branch and Long Branch (1991) and Collins and Juniper Creeks (1991-92) were recorded for a short period. To obtain coincident streamflow records for the FYE simulation, the period of record was extended using the record extension technique, MOVE.1 (Hirsch, 1982). Daily streamflow data for the three continuous-record sites and the four short-term record sites were obtained from the USGS National Water Information System (NWIS) database. Monthly streamflows were calculated from daily streamflow data for the three continuous-record sites. Monthly flows for the three sites and the record for each short-term site were used as input to a computer program written to calculate MOVE. 1 values for each site where the record was to be

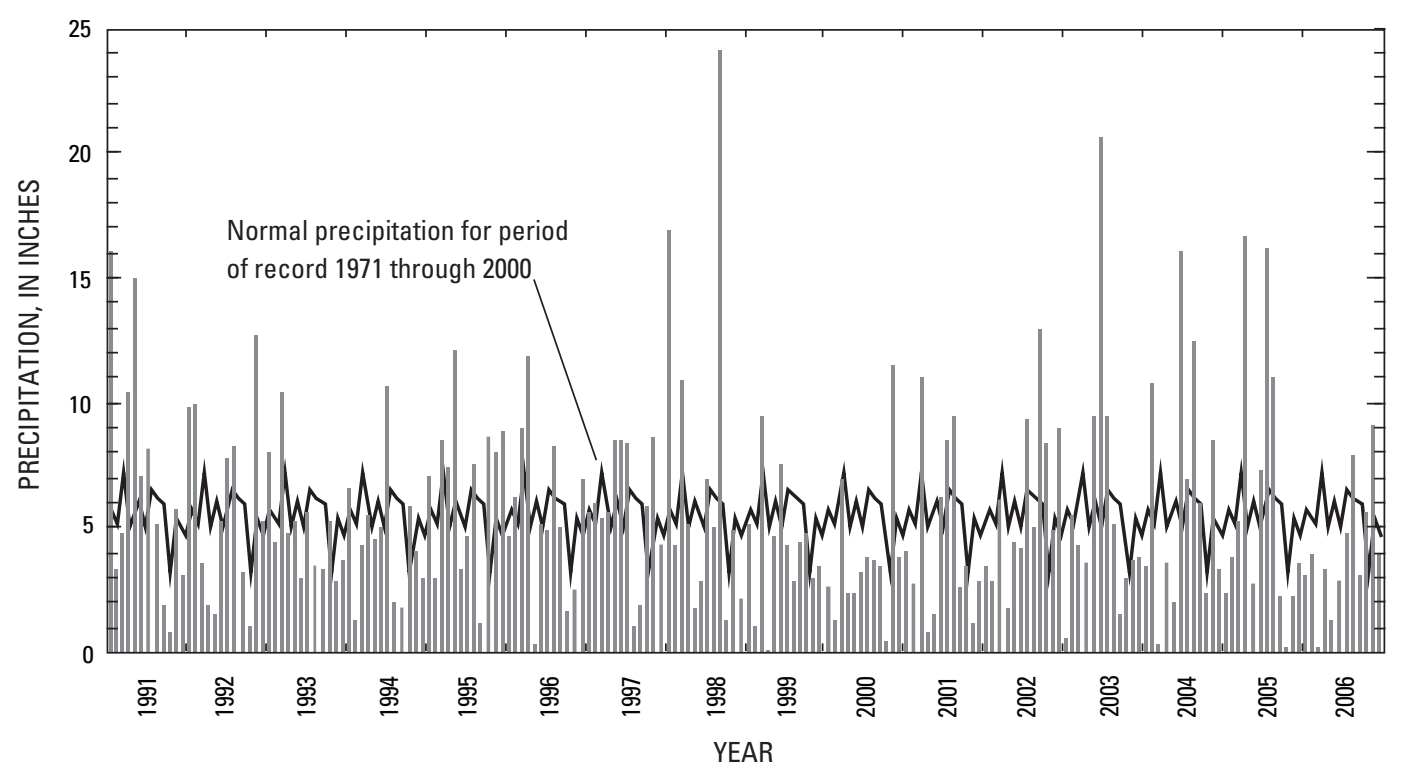

Figure 4. Monthly precipitation for 1991 through 2006 recorded at the National Weather Service station, Mobile airport, Alabama, in relation to normal monthly precipitation at this station for the period of record 1971-2000. 


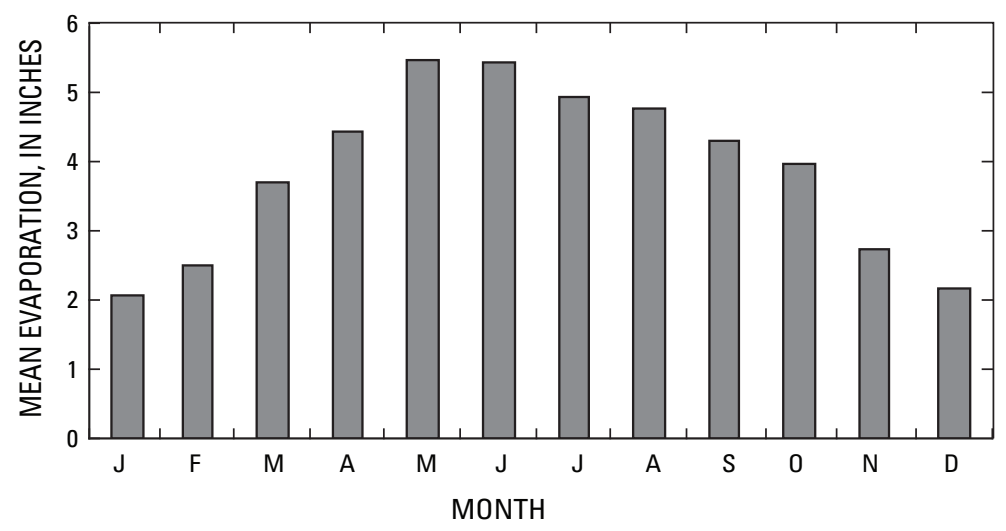

Figure 5. Mean monthly pan evaporation data obtained from the National Weather Service station at Mobile airport (Farnsworth and Thompson, 1982) and converted to free-surface evaporation using evaporation coefficients from Farnsworth and others (1982).

Table 1. Streamflow conditions for the 1991-2006 water years in selected tributaries to J.B. Converse Lake, Alabama.

[Water year is the period October 1 through September 30 and is identified by the year in which the period ends. For example, the 1991 water year began on October 1, 1990, and ended on September 30, 1991]

\begin{tabular}{|c|c|c|c|c|c|}
\hline $\begin{array}{l}\text { Station label } \\
\text { (figs. } 1 \text { and } 3 \text { ) }\end{array}$ & $\begin{array}{l}\text { Station } \\
\text { number }\end{array}$ & Station name & $\begin{array}{l}\text { Drainage area } \\
\text { (square miles) }\end{array}$ & $\begin{array}{l}\text { Period of } \\
\text { record }\end{array}$ & $\begin{array}{l}\text { Measured or estimated } \\
\text { average streamflows for the } \\
1991-2006 \text { water years } \\
\text { (cubic feet per second) }\end{array}$ \\
\hline $\mathrm{CRO}$ & 2479980 & Crooked Creek near Fairview, AL & 8.08 & $1991-2006$ & 17.2 \\
\hline HAM & 2480002 & Hamilton Creek at Snow Road near Semmes, AL & 8.22 & 1991-2006 & 22.4 \\
\hline LON & 2479955 & Long Branch near Wilmer, AL & 2.85 & 1991 & 5.5 \\
\hline \multirow[t]{2}{*}{ BOG } & 2479960 & Boggy Branch at County Road near Wilmer, AL & 3.17 & 1991 & 6.0 \\
\hline & & Total & 71.58 & & 146.3 \\
\hline
\end{tabular}

extended (Gregory E. Granato, U.S. Geological Survey, written commun., 2007). The MOVE.1 streamflow estimates from the two continuous-record sites with the best correlation (Big Creek and Crooked Creek) were averaged to obtain the final record extension for each short-term site. The average volume of surface-water flow to Converse Lake for the period 1991 through 2006, calculated by record extension of the four shortterm sites, was $44.7 \mathrm{ft}^{3} / \mathrm{s}$.

Because the area of the Converse Lake watershed drained by these seven streams is $71.6 \mathrm{mi}^{2}$ of the total Converse Lake watershed area of $104.4 \mathrm{mi}^{2}$ (Converse Lake covers about $\left.5.6 \mathrm{mi}^{2}\right)$, that leaves a smaller, ungaged drainage area of potential runoff of $27.2 \mathrm{mi}^{2}$ - about 26 percent of the total Converse Lake watershed area (fig. 3). Potential average runoff from this $27.2-\mathrm{mi}^{2}$ area was estimated to be $56.5 \mathrm{ft}^{3} / \mathrm{s}$ by the drainagearea ratio method, as applied by Ries and Friesz (2000).

Average streamflow from the three continuous-record sites was $101.6 \mathrm{ft}^{3} / \mathrm{s}$; record-extension streamflow for the four short-term record sites was estimated to be $44.7 \mathrm{ft}^{3} / \mathrm{s}$; and runoff of $56.5 \mathrm{ft}^{3} / \mathrm{s}$ was estimated by using a drainage-area ratio method for the smaller, ungaged drainage area of $27.2 \mathrm{mi}^{2}$. The resulting total average streamflow to Converse Lake for the 1991 through 2006 water-year period was $202.9 \mathrm{ft}^{3} / \mathrm{s}$. 


\section{Reservoir Characteristics}

The volume of Converse Lake is about 52,000 acre-feet, or approximately 17 billion gallons at the normal operational pool level of 110 feet (ft) above NGVD 29 (City of Mobile, Board of Water and Sewer Commissioners, written commun., October 5, 1994). Converse Lake has an average depth of $14.4 \mathrm{ft}$ at full pool, with maximum depths of more than $50 \mathrm{ft}$ near the dam and spillway. The pump station is located in a small embayment below the mouth of Hamilton Creek (fig. 1; Journey and Gill, 2001). The embayment has a maximum depth of about $27 \mathrm{ft}$. The minimum lake-level elevation for pumps to operate is about $90 \mathrm{ft}$ above NGVD 29 (Bennie White, Mobile Area Water and Sewer System, written commun., 2007).

The relations of the reservoir surface area to storage and stage to storage are based on reservoir bathymetry that relates the volume of water in available reservoir storage to reservoir surface area (surface area being a function of reservoir stage). These relations are needed to estimate total precipitation to and evaporation from the reservoir surface and to compute the ground-water contribution to reservoir storage. Data from the original 1952 reservoir construction drawings for Converse Lake bathymetry related a value of reservoir storage to a corresponding value of reservoir stage in 5 -ft increments from $90 \mathrm{ft}$ to $110 \mathrm{ft}$ (Les Brown, Mobile Area Water and Sewer System, written commun., 2008). Water storage in Converse Lake that is usable for public supply is the volume of water that corresponds to the reservoir surface elevation above $90 \mathrm{ft}$. At the reservoir surface elevation of $90 \mathrm{ft}$, which covers a surface area of about 1,180 acres, the volume of water in reservoir storage available for public supply is zero million gallons (Mgal). At a pool elevation of $110 \mathrm{ft}$, which covers an area of about 3,590 acres, the volume available for public supply is about 14,770 Mgal. Points defining the relations of surface area to storage (fig. $6 \mathrm{~A}$ ) and stage to storage (fig. $6 \mathrm{~B}$ ) were plotted in a spreadsheet program to provide a continuous relation between reservoir surface area to storage and stage to storage. Piece-wise linear equations were determined to provide the best fit for these relations; lines fit to the bathymetric data points and the corresponding coefficients used in the FYE are shown in figures $6 A, B$.

\section{Reservoir Conditions: 1994 through 2006}

The 1991 through 2006 water years include a drought that occurred during 2000. After 2000, withdrawals from Converse Lake decreased compared with withdrawals before year 2000. Although withdrawals decreased after 2000, reservoir spillage also decreased in partial response to a decrease in rainfall from 2000 through 2006. Because of the observed decreases in withdrawals and reservoir spillage, comparisons of before- and after-2000 conditions were made. For the following comparisons of conditions before and after 2000, a 6-year period of comparison was used (1994 through 1999 and 2001 through 2006). Average annual withdrawals from
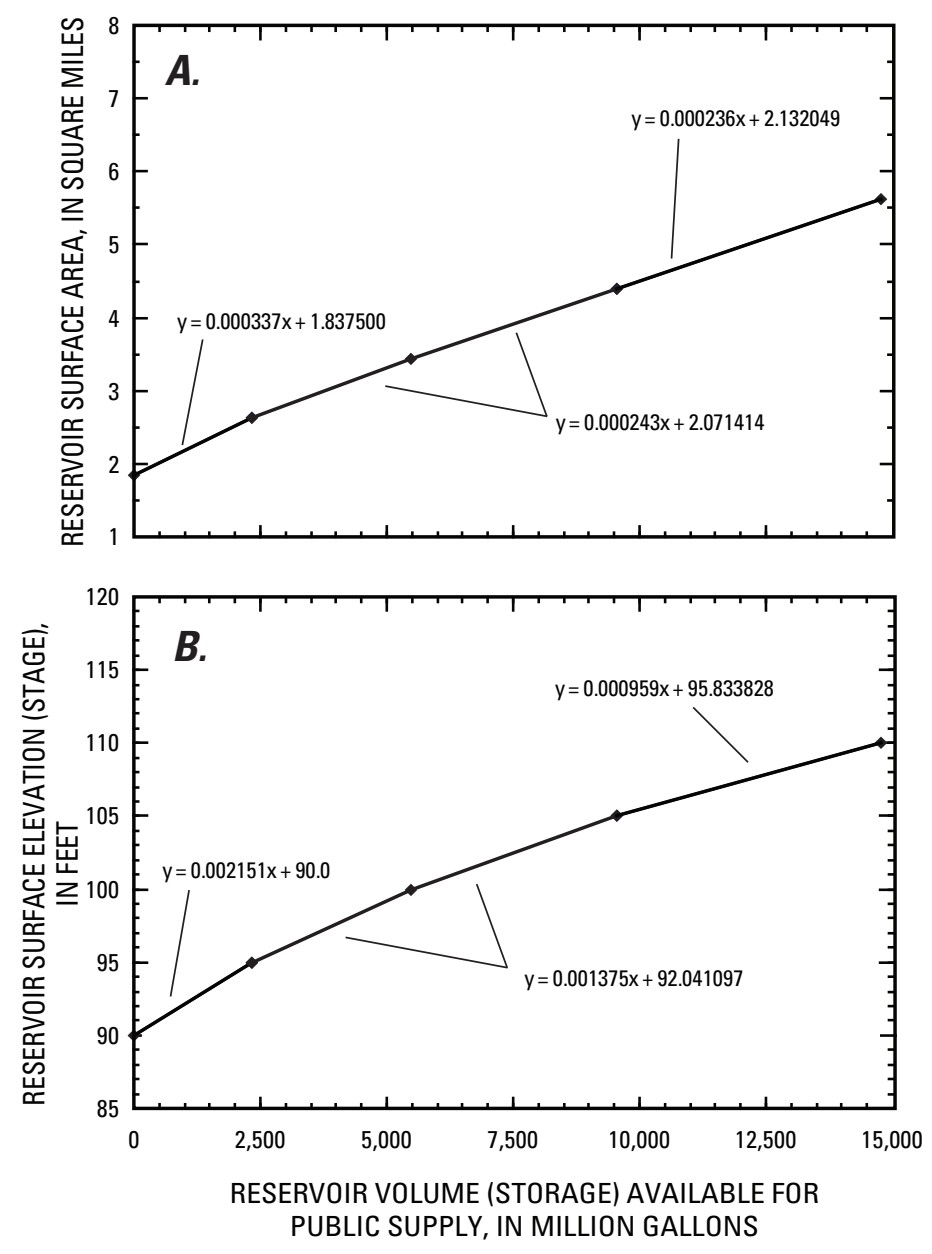

Figure 6. Coefficients of relations of $(A)$ reservoir surface area to storage and $(B)$ reservoir stage to storage for J.B. Converse Lake and for use in the firm-yield estimator.

Converse Lake were $85.6 \mathrm{Mgal} / \mathrm{d}$ for the period 1994 through 1999 and $59.37 \mathrm{Mgal} / \mathrm{d}$ for the period 2001 through 2006 (about 30 percent lower than the withdrawals during 1994-99, fig. 7). Drought-year 2000 withdrawal was $74.13 \mathrm{Mgal} / \mathrm{d}$.

Average high-lake levels for 1994 through 1999 (109.6 ft) were 0.6 percent greater than for 2001 through 2006 (109.0 ft). The average high-lake level in 2000 was $105.4 \mathrm{ft}$. Average low-lake levels for 1994 through 1999 (108.7 ft) were 0.8 percent greater than for 2001 through 2006 (107.9 ft). The average low-lake level in 2000 was $104.2 \mathrm{ft}$. Average monthly rainfall recorded at the National Weather Service station at Mobile airport for 1994 through 1999 (5.7 in.) was 3 percent greater than the average monthly rainfall for 2001 through 2006 (5.5 in.). The average monthly rainfall for 2000 was 3.8 in. (National Oceanic and Atmospheric Administration, 2007). Although these changes appear to be minor, they can have a large effect on reservoir spillage. Average spillage from the lake for 1994 through $1999\left(131.7 \mathrm{ft}^{3} / \mathrm{s}\right)$ was 17 percent greater than the average spillage for 2001 through $2006\left(109.3 \mathrm{ft}^{3} / \mathrm{s}\right)$. No spillage occurred in 2000. 


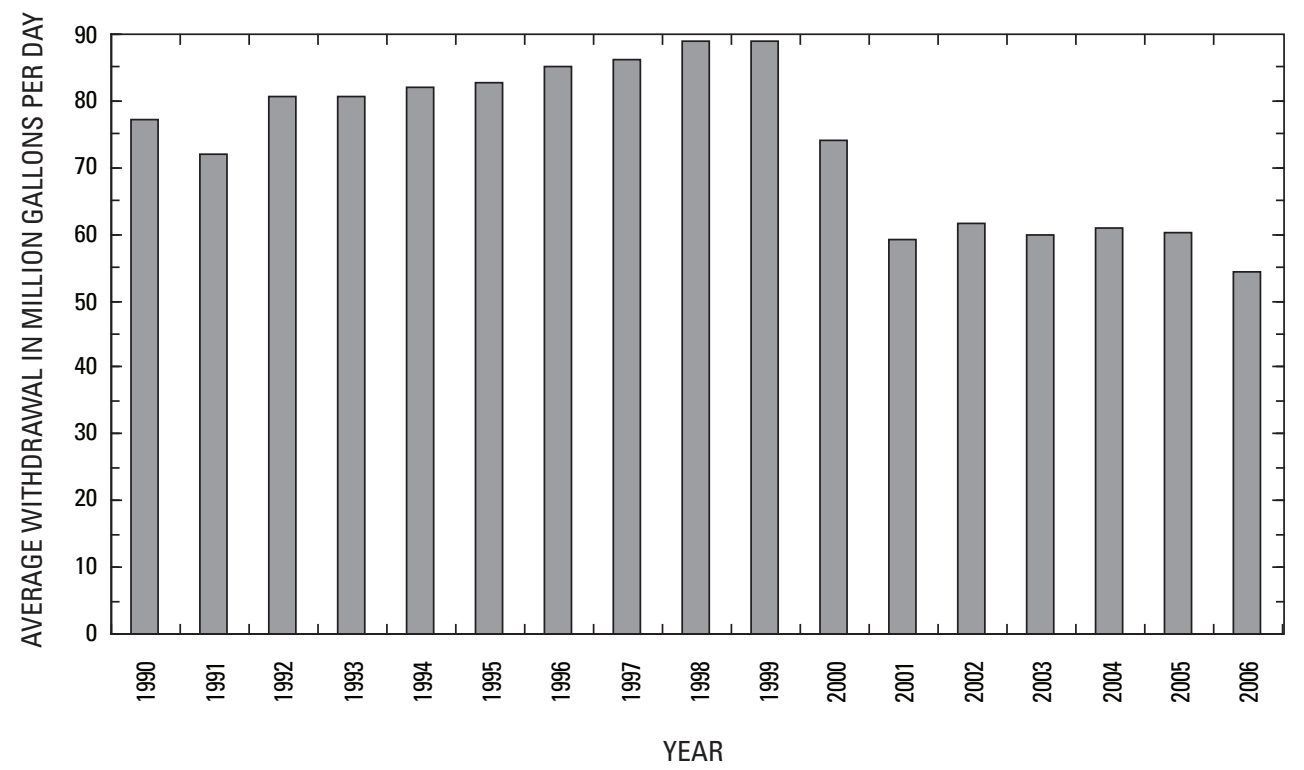

Figure 7. Average withdrawals from J.B. Converse Lake in Alabama for public supply, in million gallons per day, for the period 1990 through 2006.

Overall, the 6-year period following the drought in 2000 showed Converse Lake having decreases in withdrawals, average high- and low-lake levels, spillage, and rainfall. The withdrawals decreased by about 30 percent, and spillage decreased by 17 percent in partial response to an average annual decrease in precipitation of about 3 percent ( 2.4 in. per year). These results highlight the relative importance of small changes in precipitation on reservoir response.

\section{Geologic Setting}

The Converse Lake watershed is underlain by an undifferentiated sedimentary deposit of Miocene age (named Miocene Series undifferentiated) and by the Citronelle Formation of Pliocene age. These units compose the major aquifer system that contributes ground water to streams and lakes in the Converse Lake watershed.

\section{Major Hydrogeologic Units}

Two geologic units consisting of semiconsolidated sand, silt, gravel, and clay underlie the Converse Lake watershed (fig. 3). The two units are undifferentiated sedimentary deposits of Miocene age (named Miocene Series undifferentiated) overlain by the Citronelle Formation of Pliocene age. The units thicken to the southwest (Journey and Gill, 2001). The Miocene Series undifferentiated is of marine and estuarine origin and consists of laminated to thinly bedded, laterally extensive clays, sands, and sandy clays. The unit is about 3,000 ft thick near the coast. The Citronelle Formation is relatively thin (about $30 \mathrm{ft}$ ) in the northern part of the watershed but thickens toward the south to about $130 \mathrm{ft}$ near the coast. The Citronelle Formation consists of gravelly sands and sandy clays with thin
( 5 to $15 \mathrm{ft}$ thick) lenses of sandy clay and clayey sand interbedded with gravelly sand (Journey and Gill, 2001).

The Pliocene-Miocene aquifer is the major aquifer system contributing ground water to streams and lakes in the Converse Lake watershed. Although clayey sediments in the Miocene Series undifferentiated cause the aquifer to behave as if it were semiconfined at depth, the sand and gravel beds of the Citronelle Formation and the upper part of the Miocene Series are hydraulically connected to the land surface (Journey and Gill, 2001). For the firm-yield analysis, the properties of the portion of the sand and gravel aquifer within about $100 \mathrm{ft}$ of land surface in the Converse Lake watershed are of interest.

\section{Aquifer Properties}

Although aquifer properties, such as hydraulic conductivity, transmissivity, and storage coefficients, are largely unknown for the Pliocene-Miocene aquifer, estimates of aquifer transmissivity and storage are required for the FYE to estimate a firm yield that incorporates ground-water exchange with the reservoir (Archfield and Carlson, 2006). Specificcapacity data of unknown accuracy were available for 10 wells in the general area of Converse Lake. An equation developed by Prudic (1991) for estimating transmissivity from specificcapacity data and an aquifer storage coefficient were used to calculate a range of transmissivities for the 10 wells. Because both the FYE and the Prudic (1991) equation require an aquifer-storage coefficient, these values had to be estimated. Prudic (1991) used an aquifer-storage coefficient of 0.15 in his report on the Gulf Coast Regional Aquifer System. A range of values was used to represent accepted aquifer-storage coefficients for a confined aquifer (0.0001; Gandl, 1979) to storage for an unconfined aquifer $(0.3$; Heath, 1982). This range of 
aquifer-storage coefficients (0.0001 to 0.3$)$ was used in the Prudic (1991) equation, and the resulting transmissivities from specific-capacity data for each well ranged from 6,760 to 340 feet squared per day $\left(\mathrm{ft}^{2} / \mathrm{d}\right)$, respectively (table 2$)$. Average transmissivity values for the group of 10 wells for each value of aquifer storage $(0.0001,0.1,0.15$, and 0.3$)$ were 2,993 , $1,884,1,815$, and $1,704 \mathrm{ft}^{2} / \mathrm{d}$, respectively (table 2 ). This range of coeffiecients is similar to the transmissivity values of 120 to $3,300 \mathrm{ft}^{2} / \mathrm{d}$ in the Oligocene aquifer system and 4,000 to $13,000 \mathrm{ft}^{2} / \mathrm{d}$ in the Citronelle aquifers in Mississippi reported by Gandl $(1979,1982)$. Renken (1996) reported a transmissivity of $13,000 \mathrm{ft}^{2} / \mathrm{d}$ for the water-bearing units within the Miocene sediments in Mississippi. From a regional study by Grubb (1998) that included the coastal lowlands aquifer system, estimates of hydraulic conductivity ranged from 20 to $50 \mathrm{ft} / \mathrm{d}$ in the general area of Converse Lake. If an effective aquifer thickness of $100 \mathrm{ft}$ is assumed, a corresponding estimated range of transmissivity would be from $2,000 \mathrm{ft}^{2} / \mathrm{d}$ to $5,000 \mathrm{ft}^{2} / \mathrm{d}$. Because the Citronelle Formation and Miocene Series undifferentiated geologic units that underlie Converse Lake most likely would represent an unconfined aquifer system within $100 \mathrm{ft}$ of land surface, a reasonable range for coefficients of aquifer storage from estimated and reported values would be 0.1 to 0.3 . By combining the results for transmissivity presented in table 2 and reported values discussed above, an initial range of paired transmissivity and aquifer-storage coefficients for the aquifer that underlies Converse Lake would be $400 \mathrm{ft}^{2} / \mathrm{d}$ and 0.1 to $13,000 \mathrm{ft}^{2} / \mathrm{d}$ and 0.3 , respectively.

\section{Firm-Yield Estimator Methodology and Calibration}

The firm-yield estimator (FYE) was developed by the Massachusetts Department of Environmental Protection (MassDEP) for the purpose of estimating reservoir firm yield- the maximum yield that can be delivered by the reservoir, even under drought conditions, without completely depleting available reservoir storage (Waldron and Archfield, 2006). Using the routine presented in Waldron and Archfield (2006), average daily firm yield can be estimated for a reservoir without ground-water exchange. The routine to estimate average daily firm yield without ground-water exchange is based on the FYE guidance document (Massachusetts Department of Environmental Protection, 1996) and from input data that include data from the surface-water regime in the form of total monthly surface-water flow to a reservoir (Waldron and Archfield, 2006).

Water in available storage in a reservoir can be supplemented or reduced if a reservoir is in contact with an aquifer (fig. $8 A$ ), as a result of direct inflow from the aquifer to the reservoir (fig. $8 B$ ) or direct outflow of water from the reservoir to the aquifer (fig. $8 C$ ). The direction of exchange depends on the relative elevations of reservoir stage and the watertable surface (fig. 2; Archfield and Carlson, 2006). When the reservoir shoreline is in contact with an aquifer, as is the case for Converse Lake, the effect of ground-water contributions on firm yield can be variable.

Table 2. Aquifer transmissivities calculated by using the Prudic (1991) equation and specific-capacity data and aquifer-storage coefficients $(0.0001$ to 0.3$)$ for each of 10 wells in the area of J.B. Converse Lake, Alabama.

\begin{tabular}{lcccc}
\hline \multirow{2}{*}{$\begin{array}{l}\text { Well } \\
\text { identification }\end{array}$} & \multicolumn{4}{c}{ Aquifer-storage coefficient (S) } \\
\cline { 2 - 5 } & $\mathbf{0 . 0 0 0 1}$ & $\mathbf{0 . 1}$ & $\mathbf{0 . 1 5}$ & $\mathbf{0 . 3}$ \\
\cline { 2 - 5 } Wransmissivity (T), in feet squared & per day \\
\hline WF4 & 670 & 400 & 370 & 340 \\
MOBY-07 & 890 & 500 & 480 & 440 \\
MOBX-9 & 1,420 & 830 & 800 & 740 \\
WF3 & 1,920 & 1,180 & 1,140 & 1,070 \\
MOBX-01 & 2,310 & 1,430 & 1,370 & 1,290 \\
MOBQ-01 & 3,360 & 1,520 & 1,470 & 1,390 \\
WF1 & 3,050 & 1,880 & 1,800 & 1,680 \\
MOBAA-07 & 6,650 & 2,550 & 2,470 & 2,340 \\
WF5 & 6,760 & 4,230 & 4,080 & 3,830 \\
Average & $\mathbf{2 , 9 9 3}$ & $\mathbf{1 , 8 8 4}$ & $\mathbf{1 , 8 1 5}$ & $\mathbf{1 , 7 0 4}$ \\
\hline
\end{tabular}




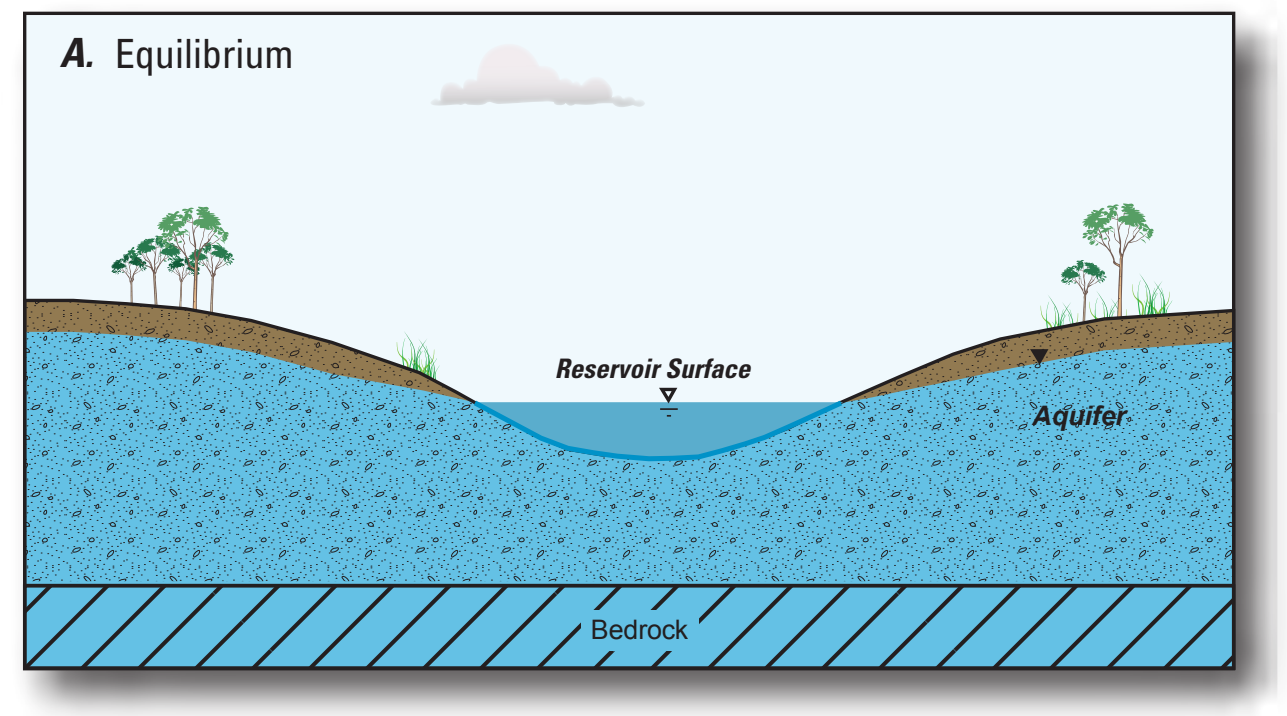

\author{
EXPLANATION \\ Unsaturated \\ Saturated \\ - Flow direction \\ $\underline{\nabla}$ Stage \\ $\checkmark$ Water table
}
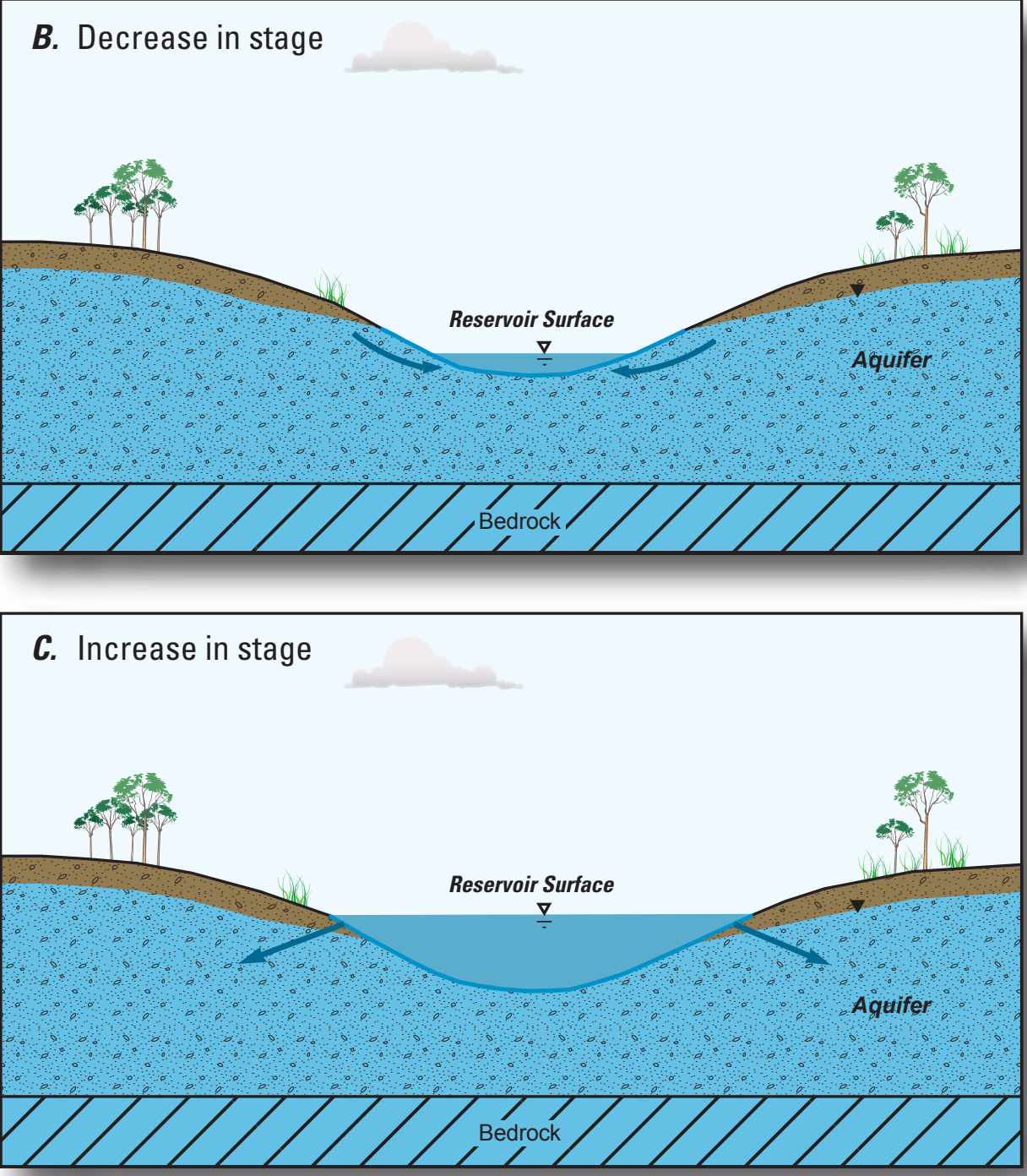

Figure 8. (A) Reservoir water level at equilibrium with the water table in the surrounding aquifer, $(B)$ response of the water table to a decrease in the water level of the reservoir relative to the water table, and (C) an increase in the water level of the reservoir relative to the water table (modified from Archfield and Carlson, 2006). 
The same routine used to estimate firm yield without ground-water exchange can be used to estimate firm yield with ground-water exchange with the addition of a term $\left(Q G W_{\mathrm{i}}\right)$ that accounts for the volume of water that moves between the reservoir and the aquifer. Firm yield with ground-water exchange is then computed by solving the monthly water balance (eq. 1) of a reservoir for a period of record that includes a drought of record (Archfield and Carlson, 2006):

$$
\begin{aligned}
S_{\mathrm{i}}= & S_{\mathrm{i}-1}+A w_{\mathrm{i}} Q r_{\mathrm{i}}+A r_{\mathrm{i}}\left(P_{\mathrm{i}}-E_{\mathrm{i}}\right) \pm Q G W_{\mathrm{i}} \\
& -\alpha_{\mathrm{i}} n_{\mathrm{i}} Q_{\mathrm{y}}-Q r_{\mathrm{i}}-Q s_{\mathrm{i}}-Q o_{\mathrm{i}}
\end{aligned}
$$

where

$$
\begin{aligned}
& i \quad \text { is the month; } \\
& S_{\mathrm{i}} \quad \text { is the water in usable storage at the end of the } \\
& \text { month, in million gallons; } \\
& S_{\mathrm{i}-1} \quad \text { is the amount of water in usable storage } \\
& \text { at the end of the previous month, } \\
& \text { in million gallons; } \\
& A w_{\mathrm{i}} \quad \text { is the contributing drainage area, } \\
& \text { in miles squared; }{ }^{2} \\
& Q r_{\mathrm{i}} \quad \text { is the streamflow per mile of reservoir } \\
& \text { drainage, in miles; }{ }^{2} \\
& A r_{\mathrm{i}} \text { is the area of the reservoir surface, } \\
& \text { in miles squared; }{ }^{2} \\
& P_{\mathrm{i}} \quad \text { is the precipitation, in miles; }{ }^{2} \\
& E_{\mathrm{i}} \quad \text { is the evaporation from the reservoir, } \\
& \text { in miles; }{ }^{2} \\
& Q G W_{\mathrm{i}} \quad \text { is the volume of water that moves between } \\
& \text { the reservoir and aquifer due to the present } \\
& \text { change in reservoir stage during the } \\
& \text { month and the time varying past changes } \\
& \text { in reservoir stage over previous months, } \\
& \text { in million gallons; }
\end{aligned}
$$

Firm-yield estimations begin with the month of April, which in Massachusetts is the month when a reservoir is most likely to be at full capacity. For most years during the 1991-2006 period, Converse Lake typically had high lake levels and spillage from January through April. Therefore, beginning estimations of firm yield in April also applies to Converse Lake. Converse Lake also refilled after the drought

\footnotetext{
${ }^{2}$ Precipitation, streamflow, and evaporation are in units of length and, when multiplied by $A r_{i}$, become volumes (in cubic miles) that are converted to million gallons.
}

of record (2000). In addition to surface-water flows to a reservoir, the FYE includes a component that accounts for the interaction of a ground-water system with a reservoir, in the case where a reservoir is in contact with a sand and gravel aquifer (Archfield and Carlson, 2006). Detailed descriptions of the FYE routines for firm yield estimated from surface-water flow (ground-water exchange is zero) are found in Waldron and Archfield (2006); an analytical method for estimating firm yield that includes both surface-water flow and ground-water exchange components (the estimate of ground-water contribution to reservoir storage) is described in Archfield and Carlson (2006). For some reservoirs in contact with an aquifer, groundwater exchange can be substantial. The report by Archfield and Carlson (2006) includes analyses of idealized reservoir geometries based on characteristics of real reservoirs. Comparisons of firm-yield estimates with observed real reservoir flows, releases, and withdrawals in Massachusetts have not yet been conducted, however, and the FYE may not be applicable to all reservoir-aquifer systems.

The firm yield is estimated as an average daily value because, for each month, a demand factor is used in the FYE that accounts for reservoir-specific demand that varies by month. The demand factor is calculated as the total withdrawal by month divided by the average withdrawal for the corresponding year. Thus, withdrawal rates may be greater or less than the firm-yield value for some months of the year. The unique monthly demand factors for each month during the 1991-2006 period are shown in figure $9 A$ for Converse Lake. Figure $9 B$ shows the average monthly demand factor for the same period used for each year in the FYE based on a set of average monthly demand factors that were determined on the basis of the most recent withdrawal data and reflective of the demand pattern most likely to occur in the future. Firmyield estimates are sensitive to demand patterns (Waldron and Archfield, 2006).

A variety of input data are used in the FYE routines to estimate an average daily firm yield of a reservoir (Archfield and Carlson, 2006; Waldron and Archfield, 2006). Some terms shown in eq. 1 are functions of other input data. For example, the area of the reservoir surface is computed from the relation of the reservoir surface area to storage. Several input variables are common to both FYE routines, including (1) total monthly surface-water flow, in million gallons per month, for all streams flowing into the reservoir; (2) monthly precipitation, in inches; (3) average monthly evaporation from the reservoir surface, in inches; (4) required releases from the reservoir for in-stream flow purposes, in million gallons per month, if any; (5) a unique monthly demand factor calculated by dividing the monthly withdrawals by the average withdrawals for the year (dimensionless, fig. 9B); (6) the contributing drainage area to the reservoir, in miles squared; (7) the maximum capacity of usable reservoir storage, in million gallons; (8) the bathymetry of the reservoir, in feet; and (9) the relation of the reservoir surface area to storage, in miles squared and million gallons. Additional input variables used by the FYE routine to estimate ground-water exchange are (1) $a$, the average distance from 

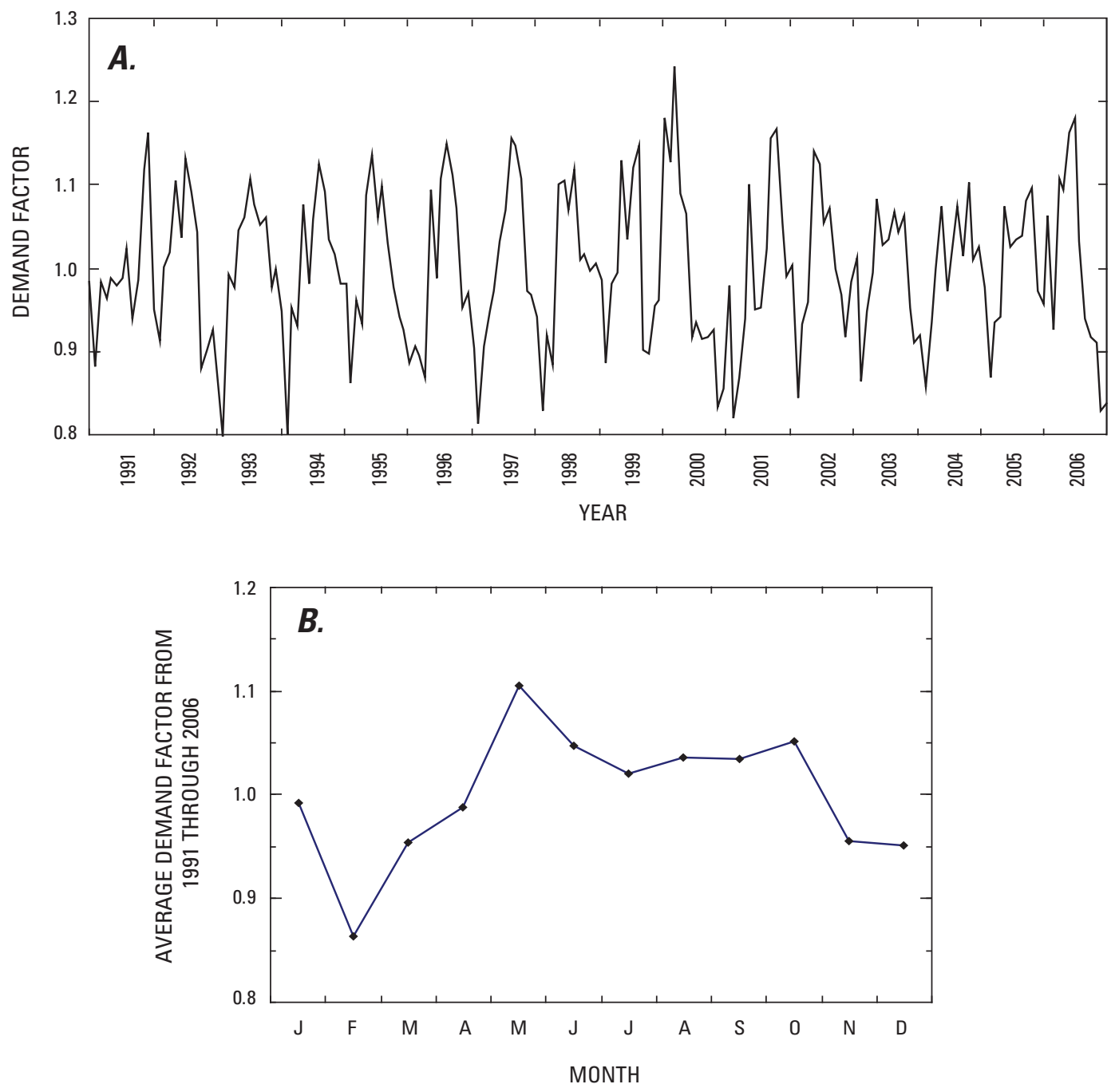

Figure 9. Factors used in the firm-yield estimator to represent $(A)$ monthly demand for the period 1991-2006 calculated as total withdrawals by month divided by the average withdrawal for the corresponding year and $(B)$ the average demand for the period 1991-2006 for J.B. Converse Lake in Alabama.

the reservoir shoreline to the aquifer boundary (representing the size of the aquifer, in feet); (2) $L$, the length of the reservoir shoreline in contact with the aquifer (represents the size of the reservoir, in feet); (3) T, the aquifer transmissivity, in feet squared per day; (4) S, aquifer storage coefficient (dimensionless); and (5) the stage to storage relation based on reservoir bathymetry that relates reservoir storage to reservoir surface area (surface area being a function of reservoir stage), in million gallons and feet, respectively.

The average distance from the reservoir shoreline to the aquifer boundary, $a$, which represents the size of the aquifer (fig. 10) was determined by calculating the average of (1) 103 representative measurements (in all four directions-east, west, north, and south - from the reservoir) and (2) another set of three representative measurements (west, north, and east from the reservoir) perpendicular from the edge of the reservoir to the aquifer boundary. The overall average of each set of measurements then was calculated to be $25,771 \mathrm{ft}$, and this value was used in the FYE (fig. 10). From this relatively large value, the aquifer can be assumed to be infinite in terms of the FYE (Archfield and Carlson, 2006). The ground-water divide is assumed to coincide with the surface-water divide.

The length of the reservoir shoreline in contact with the aquifer, $L$, represents the size of the reservoir and was determined from a geographic information system (GIS) coverage of Converse Lake (U.S. Geological Survey, Alabama Water Science Center, written commun., April 2, 2007). This length, measured at $266,402 \mathrm{ft}$, represents a detailed outline of the reservoir shoreline in contact with the aquifer (fig. 10). Two other measurements of $L$ were made to represent simplified outlines of the reservoir that included incrementally fewer shoreline details, such as coves and embayments. These measurements represent predominant general shoreline segments that are perpendicular to the assumed major ground-water flow lines representing the path of potential water exchange between the aquifer and the reservoir (fig. 10). These simplified values of 


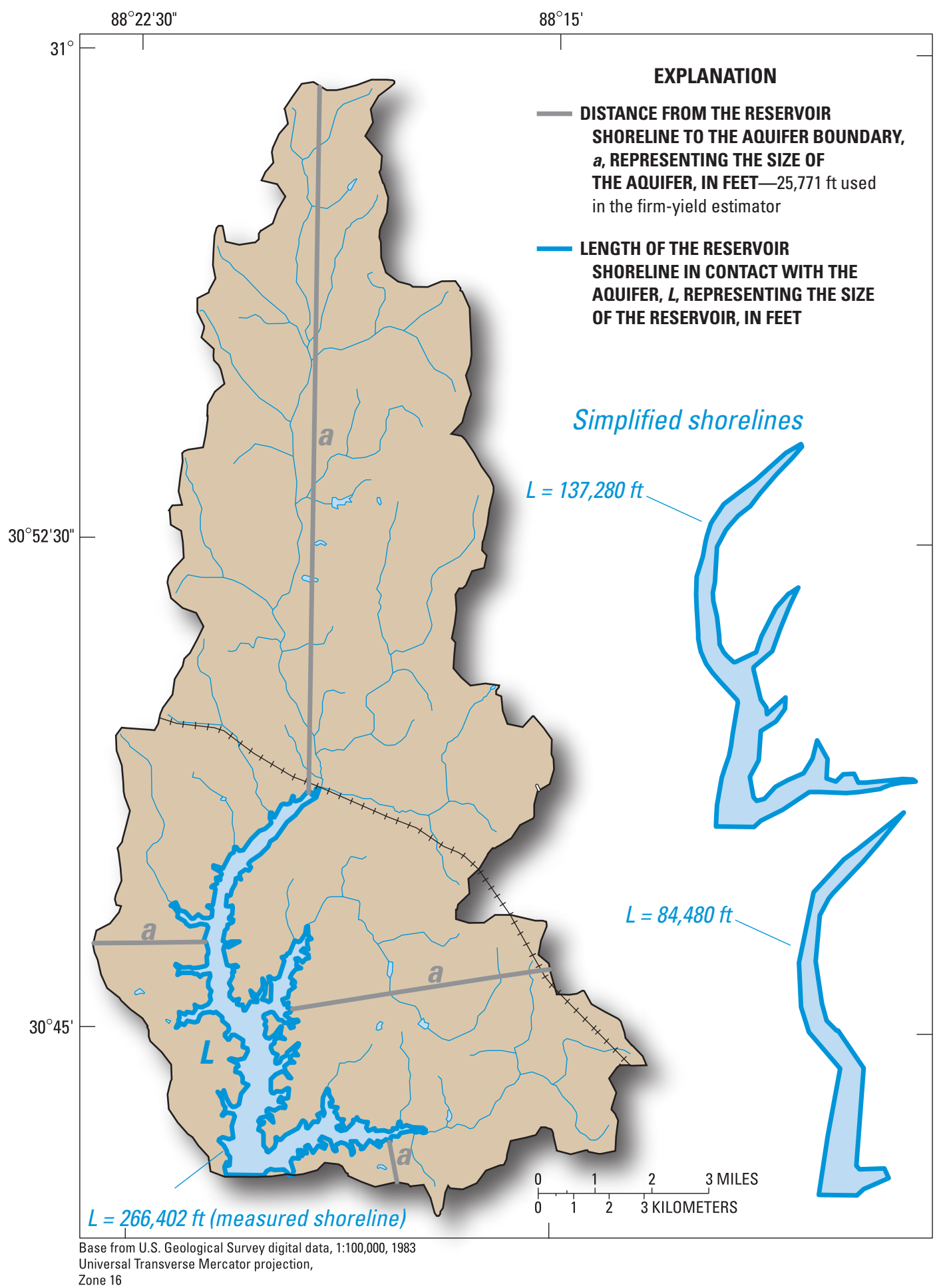

Figure 10. Variables that represent the distance from the reservoir shoreline to the aquifer boundary, $a$, and the length of the reservoir shoreline in contact with the aquifer, $L$, used for the ground-water exchange component of firm yield for a reservoir in contact with a sand and gravel aquifer, J.B. Converse Lake, Alabama. [Measured actual shoreline outline ( $L=266,402$ feet) and two simplified shoreline outlines $(137,280$ feet and 84,480 feet) are included.] 
$L$ were 137,280 ft (about 48 percent less) and 84,480 ft (about 68 percent less). The amount of Converse Lake shoreline in contact with the aquifer was 100 percent (fig. 10).

To further refine estimates of transmissivity and aquifer storage, the FYE was calibrated to match the lowest measured water level that occurred in October of drought-year 2000. The parameters that were adjusted as part of the calibration process were transmissivity and aquifer-storage coefficients. The initial values of paired transmissivity $(\mathrm{T})$ and aquifer storage $(\mathrm{S})$ ranged from $400 \mathrm{ft}^{2} / \mathrm{d}$ and 0.1 to $13,000 \mathrm{ft}^{2} / \mathrm{d}$ and 0.3 , respectively.
$\mathrm{T}$ and $\mathrm{S}$ were varied iteratively to match water-level data for a specified withdrawal rate. Simulations were made to match the lowest measured average monthly lake level $(101.7 \mathrm{ft}$ ) that occurred in October 2000 (figs. 11A,B). The average withdrawal from Converse Lake (74.13 Mgal/d) for drought-year 2000 was used as the specified withdrawal rate, and several simulations were run in which $\mathrm{T}$ and $\mathrm{S}$ were adjusted until the lowest simulated lake level for year 2000 matched the lowest measured average monthly lake level for year 2000 (101.7 ft). The various non-unique combinations of aquifer properties and other values that produced a match with

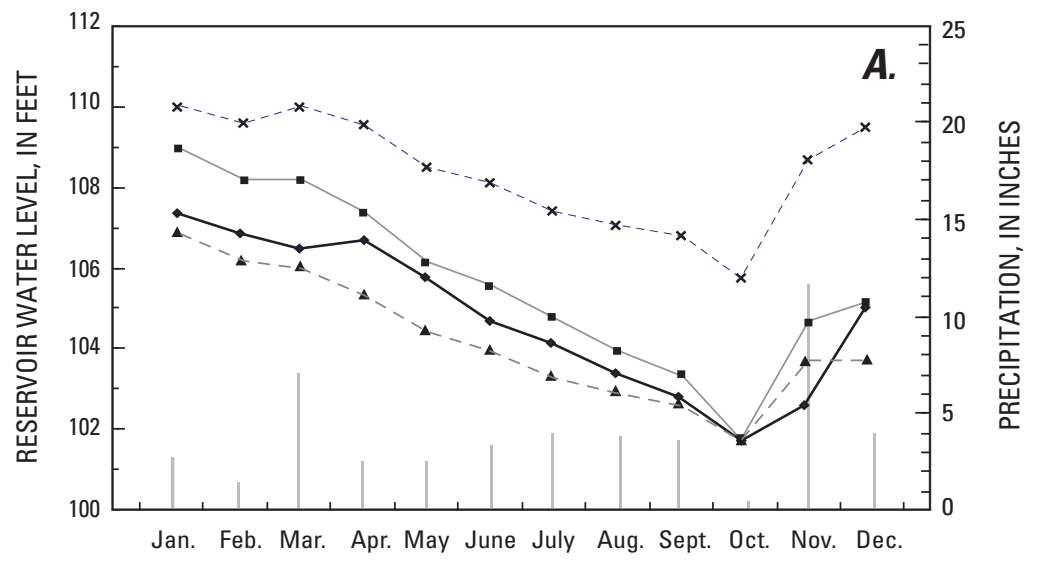

YEAR 2000

\section{EXPLANATION}
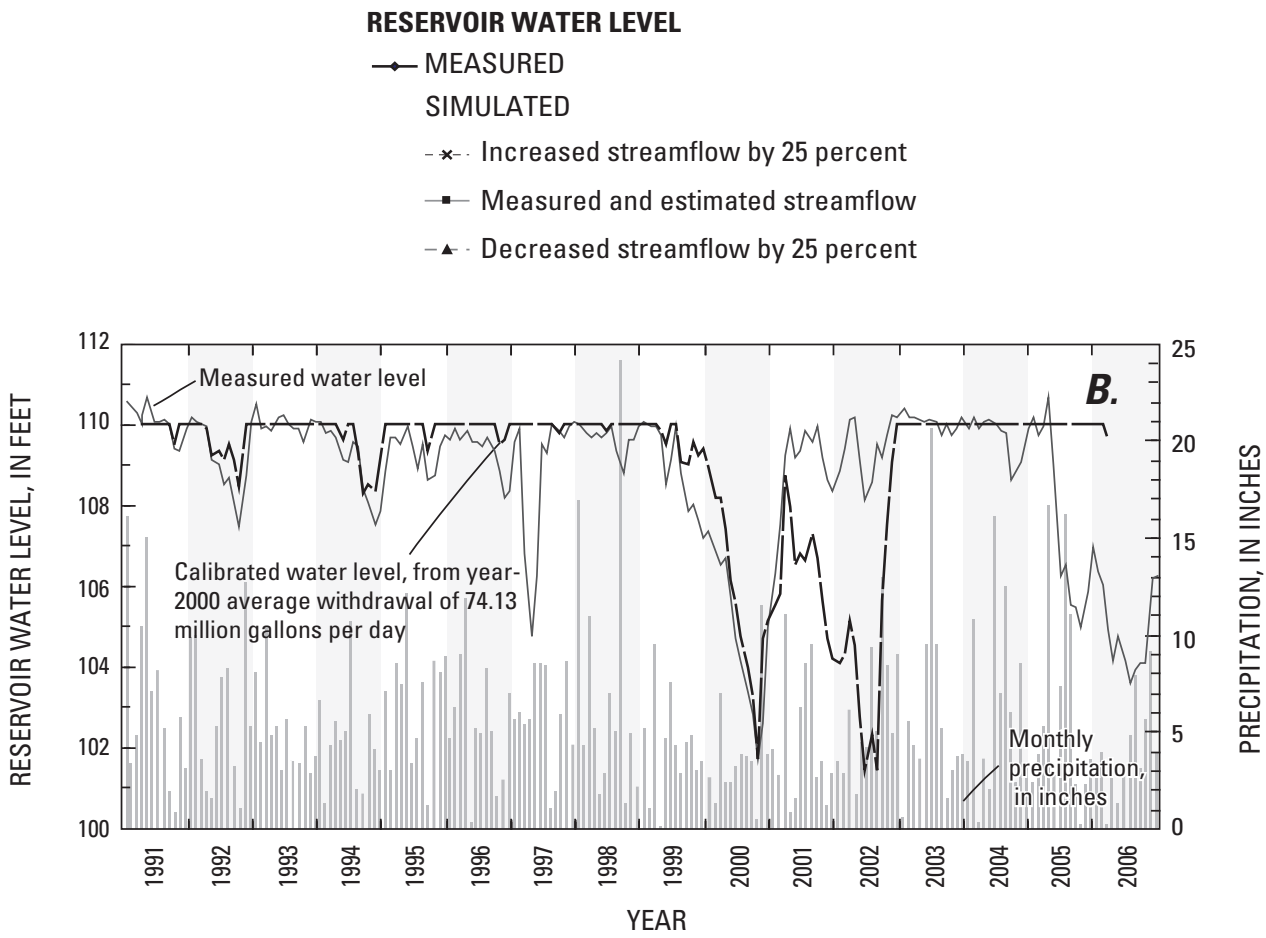

Figure 11. Simulated and measured reservoir water levels for $(A)$ droughtyear 2000 and $(B)$ the period 1991 through 2006 for model calibration simulations run to match the lowest measured drought-year 2000 water level (101.7 ft) to estimate aquifer transmissivity for J.B. Converse Lake, Alabama. 
the lowest measured average monthly lake level for year 2000 (October) are shown in table 3.

Although the goal of calibration was to reproduce drought-year 2000 water levels (fig. 11A) by using the year2000 average withdrawal rate of $74.13 \mathrm{Mgal} / \mathrm{d}$, the overall match between simulated and measured water levels is good for most years during the 1991 through 2006 period (fig. 11B). The underestimation of reservoir water levels from mid-2001 to mid-2002 may reflect (in terms of the monthly demand factor, fig. 9A) that real withdrawal rates during this period (fig. 7) decreased substantially from the year-2000 value of $74.13 \mathrm{Mgal} / \mathrm{d}$. This match shows that the FYE is capable of reproducing measured reservoir water levels given a set of aquifer properties. Other deviations of simulated water levels from measured reservoir water levels may be a result of controlled spills, which were not simulated. Validation from field study and measurement of these aquifer properties, specifically $\mathrm{T}$ and $\mathrm{S}$, could produce a more accurate result.

The most reasonable set of values for use in the FYE from the calibration process was determined to be $a$ equals $25,771 \mathrm{ft}$; $\mathrm{S}$ equals $0.15 ; L$ equals $137,280 \mathrm{ft}$; and the actual measured and estimated total surface-water flow to Converse Lake (average of $202.9 \mathrm{ft}^{3} / \mathrm{s}$ ). The transmissivity value of $650 \mathrm{ft}^{2} / \mathrm{d}$ resulted from specifying the aforementioned values in the calibration process (table 3 ). If the depth of the aquifer in hydrologic contact with Converse Lake is assumed to be $100 \mathrm{ft}$ and $\mathrm{T}$ is $650 \mathrm{ft}^{2} / \mathrm{d}$, the corresponding value of hydraulic conductivity is $6.5 \mathrm{ft} / \mathrm{d}$.

Because in the calibration process $\mathrm{T}$ and $\mathrm{S}$ are nonunique parameters that depend on $a, L$, and total surface-water flow, a sensitivity analysis was conducted using the known uncertainty in these values to determine a reasonable range of $\mathrm{T}$ and $\mathrm{S}$ for use in the firm-yield analysis. This sensitivity analysis used total monthly surface-water flows to the lake for 1991 through 2006, the unique monthly demand factor for withdrawals from Converse Lake (fig. 9A) for each month in 1991 through 2006, the drought year-2000 average withdrawal of $74.13 \mathrm{Mgal} / \mathrm{d}$ specified in the calibration process, and other input variables. The aquifer storage coefficient used in the calibration process for most simulations was 0.15 (Prudic, 1991). Calibration simulations also were run with adjustments made to $S$ (values of 0.15 and 0.25 ), the length of shoreline in contact with the aquifer, $L$, (values of 84,480, 137,280, and $266,402 \mathrm{ft}$ ) and increasing and decreasing total surface-water flow by 25 percent to determine how changes in these values would affect estimated $\mathrm{T}$.

The value for aquifer storage (0.15) was that used by Prudic (1991) to estimate $T$ for an aquifer surrounding a well less than $150 \mathrm{ft}$ in depth. In this report, the depth of the aquifer in hydrologic contact with Converse Lake was estimated to be
$100 \mathrm{ft}$. Therefore, an $\mathrm{S}$ value of 0.15 could be applicable to the aquifer in the Converse Lake watershed. Archfield and Carlson (2006) indicate that the equations used in the FYE provide a reasonable approximation of numerically simulated flow rates between a reservoir and aquifer (within \pm 10 percent) when the ratio of $a$ to $L$ is between approximately 0.5 and 2.3, regardless of the shape of the reservoir shoreline in contact with the aquifer. In this report a ratio of $0.19-$ when $a$ is $25,771 \mathrm{ft}$ and $L$ is $137,280 \mathrm{ft}$ - is the closest result to that ratio range for the combinations of $a$ and $L$ used. Also, an $L$ value of $266,402 \mathrm{ft}$ is likely to be too large from too much shoreline detail, and a value of $84,480 \mathrm{ft}$ may be too small from over-simplification of shoreline detail.

Surface-water flow is an important component of the firm-yield analysis. Although total surface-water flow to Converse Lake was either measured or estimated using accepted techniques (Hirsch, 1982; Ries and Friesz, 2000), error bars can be associated with measured and estimated surface-water flow values. Therefore, surface-water flow to Converse Lake was increased and decreased by 25 percent to determine how $\mathrm{T}$ and, consequently, firm yield could be affected. When $L$ varied from $84,480 \mathrm{ft}$ to $266,402 \mathrm{ft}$ (table 3 ), and monthly surfacewater flow totals decreased by 25 percent, $T$ varied from 4,850 to $82,500 \mathrm{ft}^{2} / \mathrm{d}$; when surface-water flow totals increased by 25 percent, $\mathrm{T}$ was set at $0.0001 \mathrm{ft}^{2} / \mathrm{d}$ (essentially no exchange of ground water with the reservoir) (table 3 ). When surfacewater flow totals were decreased by 25 percent, most firmyield-estimator solutions did not converge; therefore, these combinations of input values may not be realistic (table 3 ). When surface-water flow totals were increased by 25 percent, the measured water level of $101.7 \mathrm{ft}$ was not matched. Even with a $\mathrm{T}$ of 0.0001 , the lowest calculated water level was $105.8 \mathrm{ft}$ (fig. 11A); therefore, an increase in total surface-water flow of 25 percent may not be realistic (table 3, fig. 11A). The closest match to year-2000 water levels was the result of the calibration simulations that used the original total measured plus estimated surface-water flow that averaged $202.9 \mathrm{ft}^{3} / \mathrm{s}$ (fig. 11A).

The values of $\mathrm{T}$ that resulted from all simulations run with combinations of other realistic variables (table 3 ) that matched the measured drought-year 2000 lowest average monthly lake level were consistent with $\mathrm{T}$ estimated from the Prudic (1991) equation (table 2). Therefore, the resulting overall range of $\mathrm{T}$ was 170 to $6,760 \mathrm{ft}^{2} / \mathrm{d}$. With the assumption that measured and estimated surface-water flow are reasonable $\left(202.9 \mathrm{ft}^{3} / \mathrm{s}\right)$, a calibrated value for $\mathrm{T}$ is $650 \mathrm{ft}^{2} / \mathrm{d}$. This range of $\mathrm{T}$ in conjunction with the assumed uncertainties in $\mathrm{S}, L$, and total surface-water flow were used to assess the uncertainty in model predictions of firm yield for Converse Lake. 

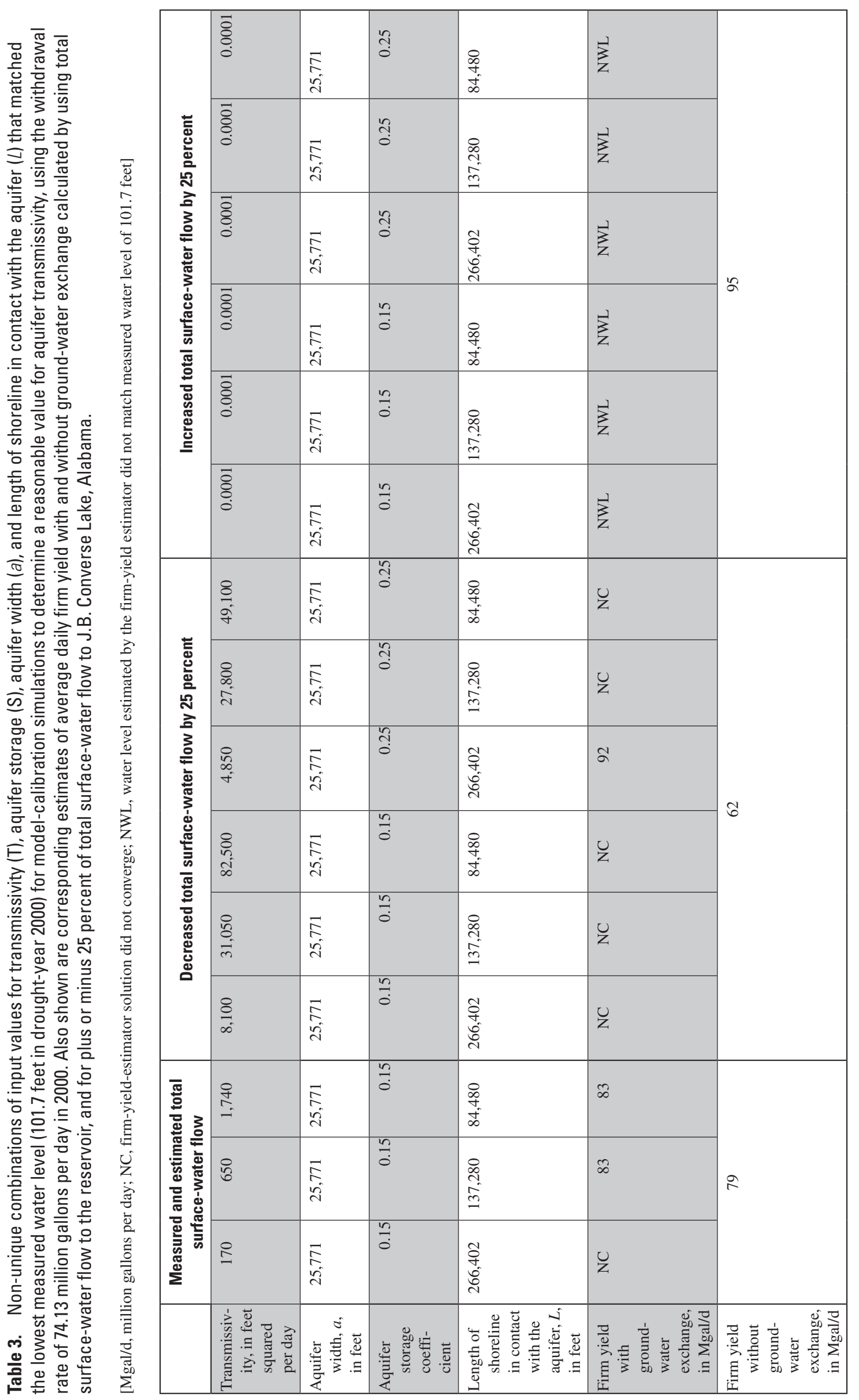


\section{Firm-Yield Assessment of J.B. Converse Lake}

Once all input variables required for the FYE were determined, the average daily firm yield was estimated for Converse Lake in two different ways: (1) with total surfacewater flow to the reservoir without ground-water exchange and (2) with total surface-water flow to the reservoir with groundwater exchange using the range of $\mathrm{T}$ and $\mathrm{S}$ values determined from model calibration.

The FYE routine (Waldron and Archfield, 2006) to estimate the average daily firm yield of a reservoir from input data that included data from the surface-water regime- total surface-water flow to the reservoir-was used to estimate an average daily firm yield for Converse Lake of $79 \mathrm{Mgal} / \mathrm{d}$ (table 3). This value represents a conservative estimate because it is based on measured plus estimated surface-water flows to Converse Lake.

The firm-yield estimate incorporating the effects of ground-water and surface-water exchange based on the best available estimates of $a$ (equals 25,771 ft), $L$ (equals
137,280 ft), $\mathrm{S}$ (equals 0.15), T (equals $650 \mathrm{ft}^{2} / \mathrm{d}$ ), and measured and estimated average surface-water flow of $202.9 \mathrm{ft}^{3} / \mathrm{s}$ resulted in an average daily firm yield of $83 \mathrm{Mgal} / \mathrm{d}$. The aquifer properties ( $\mathrm{T}$ and $\mathrm{S}$ ) used in this analysis were derived from the model calibration process; if future studies are conducted to better estimate $\mathrm{T}$ and $\mathrm{S}$, the degree of interaction between the ground-water system and the reservoir can be determined more accurately.

Usable reservoir storage for the period April 1991 through March 2006 resulting from the estimated firm-yield values of 79 and $83 \mathrm{Mgal} / \mathrm{d}$, are shown in figures $12 A, B$, respectively. These graphs (figs. $12 A, B$ ) represent available reservoir storage for a withdrawal rate equal to the respective average daily firm-yield value applied as a constant withdrawal rate throughout the April 1991 through March 2006 period to Converse Lake. Precipitation for the period is shown on each graph. Additionally, the graph in figure $12 B$ shows the simulated water flow into the reservoir or into the aquifer that resulted from the firm-yield analyses that included groundwater exchange with the reservoir.

The graph (fig. 12A) of simulated usable reservoir storage resulting from the firm-yield estimate of $79 \mathrm{Mgal} / \mathrm{d}$ that

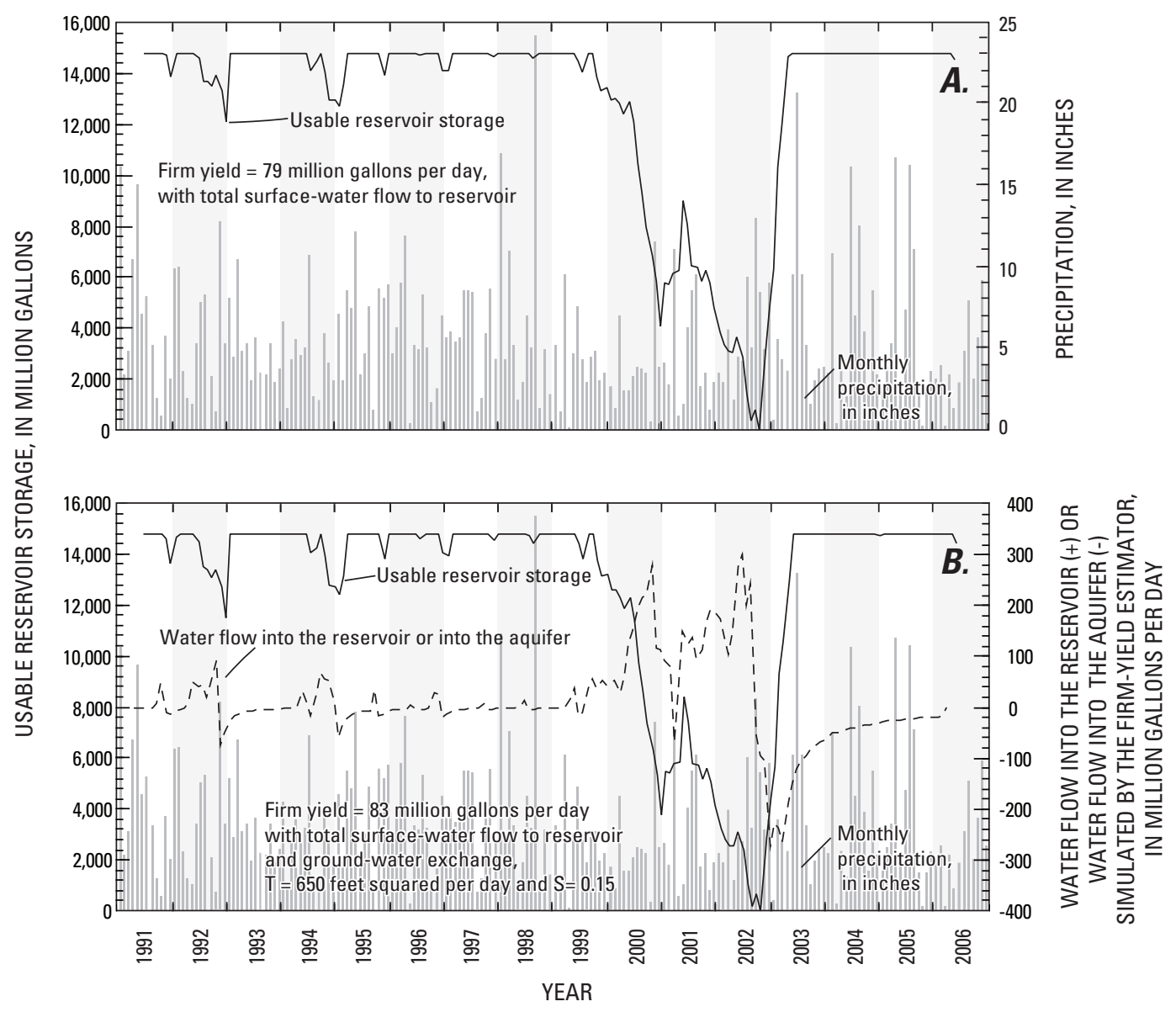

Figure 12. Total measured monthly precipitation and estimated usable reservoir storage for the period 1991-2006 for each average daily firm-yield estimate of (A) 79 million gallons per day and (B) 83 million gallons per day for J.B. Converse Lake, Alabama. 
included surface-water flows to the reservoir (no ground-water exchange) indicates that the reservoir nearly failed in November 2002. Similarly, the graph (fig. 12B) that represents simulated usable reservoir storage for firm yield with surface-water flows and ground-water exchange $\left(\mathrm{T}=650 \mathrm{ft}^{2} / \mathrm{d}\right.$ and $\left.\mathrm{S}=0.15\right)$ also indicates that reservoir near-failure occurred in November 2002. These results indicate that Converse Lake is largely affected by the amount of surface-water inflow.

Simulations of the reservoir showed that the reservoir refilled to capacity after 2002 when no interaction between the aquifer and reservoir was simulated (fig. 12A) and also when ground-water exchange was included (fig. 12B). Simulated water flow into the reservoir or into the aquifer from the firmyield analysis (fig. 12B) indicates that water began to flow into the aquifer during 2002 at a comparatively greater rate and then tailed off gradually in an asymptotic manner until the beginning of 2006. This pattern could indicate that the aquifer was still recovering from its relative depletion from movement of ground water to the reservoir during and after drought-year 2000 , by continued accumulation of precipitation recharge and from inflow of water to the aquifer from the reservoir (fig. 12B). The amount of water available in the aquifer by 2001 as supplemental inflow to the reservoir may have been lower than that available prior to drought-year 2000. Measured data for ground-water levels in wells near Converse Lake could provide information to confirm or refute this possibility. Months when total monthly precipitation exceeded 10 in. may have reduced the time needed to refill the reservoir and could be important to aquifer recharge. A potential lag in aquifer recovery time may affect the degree of ground-water interaction with the reservoir.

The measured withdrawal of $74.13 \mathrm{Mgal} / \mathrm{d}$ from Converse Lake during drought-year 2000 provides data that support the idea of a system in which ground water interacts with the reservoir. No spillage from the reservoir occurred in year 2000, however, and because withdrawals from Converse Lake were lower after 2000, it is unclear how withdrawal rates prior to 2000 may have affected water levels and the volume of usable reservoir storage in Converse Lake. After the 2000 drought (2001 through 2006), withdrawals were about 30 percent lower, rainfall was about 3 percent lower, average high-lake level was about 0.6 percent lower, and average low-lake level was about 0.8 percent lower than during the period 1994-99; average spillage from the reservoir was about 17 percent lower. Although withdrawals declined substantially compared with pre-drought withdrawals, lower spillage from Converse Lake occurred after year 2000. This result may also indicate that ground-water levels in the surrounding aquifer may take several years to recover from a drought, such as occurred in 2000.

\section{Model Limitations and Uncertainty}

Although estimates of firm yield are based on measured and estimated parameters as input to the FYE, each of the parameters has a level of uncertainty that can affect model results. The uncertainties associated with each of these parameters are as follows: $a(17,982$ to $31,637 \mathrm{ft}) ; L(84,480$ to $266,402 \mathrm{ft}$ ); $\mathrm{S}$ (0.1 to 0.3$)$; $\mathrm{T}$ (170 to $6,760 \mathrm{ft}^{2} / \mathrm{d}$ ); and plus or minus 25 percent in total measured and estimated surfacewater flow to Converse Lake. Simulations were conducted based on these ranges of values to provide a range in estimated firm yield given the limitations of the input parameters (table 4A). Although total surface-water flows were varied by 25 percent, the results listed in the "Firm-Yield Estimator Methodology and Calibration" section of this report show that an increase or decrease of 25 percent in total surface-water flow into Converse Lake may not be realistic for this analysis. The best available estimates of $a$ (equals $25,771 \mathrm{ft}$ ), $L$ (equals $137,280 \mathrm{ft}$ ), S (equals 0.15), T (equals $650 \mathrm{ft}^{2} / \mathrm{d}$ ), and measured and estimated average surface-water flow (202.9 $\left.\mathrm{ft}^{3} / \mathrm{s}\right)$ were used for the respective values in the sensitivity analysis when one or more of the other values varied. Average daily firm yield estimated from the best available estimates of these properties was $83 \mathrm{Mgal} / \mathrm{d}$, and with overall changes in these properties, firm yield ranged from 80 to $98 \mathrm{Mgal} / \mathrm{d}$ (table $4 A$ ).

The value for $a$, the aquifer size based on the average distance from the reservoir shoreline to aquifer boundary, was measured. Although this value was measured and the best representative value for $a(25,771 \mathrm{ft})$ was used in the firmyield estimation, uncertainty is associated with the measurement because of the wide range of distances from Converse Lake to the aquifer boundary. For example, the representative distance on the west side of Converse Lake is about $6,000 \mathrm{ft}$; to the north, about $64,000 \mathrm{ft}$; to the east, about $24,000 \mathrm{ft}$; and to the south, about 5,000 ft (fig. 10). The range of $a$ values examined in this report was 17,982 to $31,637 \mathrm{ft}$. By lowering $a$ by 30 percent and increasing $a$ by 23 percent for $S$ values $(0.1$ to 0.3 ) and $\mathrm{T}$ values up to $13,000 \mathrm{ft}^{2} / \mathrm{d}$, firm yield changed by less than about 1 percent. For the FYE, this indicates that the aquifer can be assumed to be infinite.

The results of the sensitivity analysis of varying the parameters $L, \mathrm{~S}$, and $\mathrm{T}$ are given in table 4A. Varying $L$ from 84,480 to $266,402 \mathrm{ft}$ caused average daily firm yield to decrease by about 2 percent $(81 \mathrm{Mgal} / \mathrm{d})$. Varying $\mathrm{S}$ from 0.1 to 0.3 caused firm yield to decrease by about 1 percent (82 Mgal/d). Varying T from 170 to $1,740 \mathrm{ft}^{2} / \mathrm{d}$ caused firm yield to decrease by about 2 percent $(81 \mathrm{Mgal} / \mathrm{d})$. In the results of the sensitivity analysis listed above, the firm-yield estimator did not converge on a solution when the best available estimates were combined with values at the higher end of the 
Table 4. Estimates of average daily firm yield for J.B. Converse Lake, Alabama, calculated with total surface-water flow and groundwater exchange with the reservoir using results of $(\mathrm{A})$ the firm-yield estimator model-calibration process and sensitivity analysis and (B) values from table 2 for various values of transmissivity (T), aquifer storage (S), aquifer width (a), and length of shoreline in contact with the aquifer $(L)$.

[NC, Firm-yield-estimator solution did not converge; —, Firm yield not calculated]

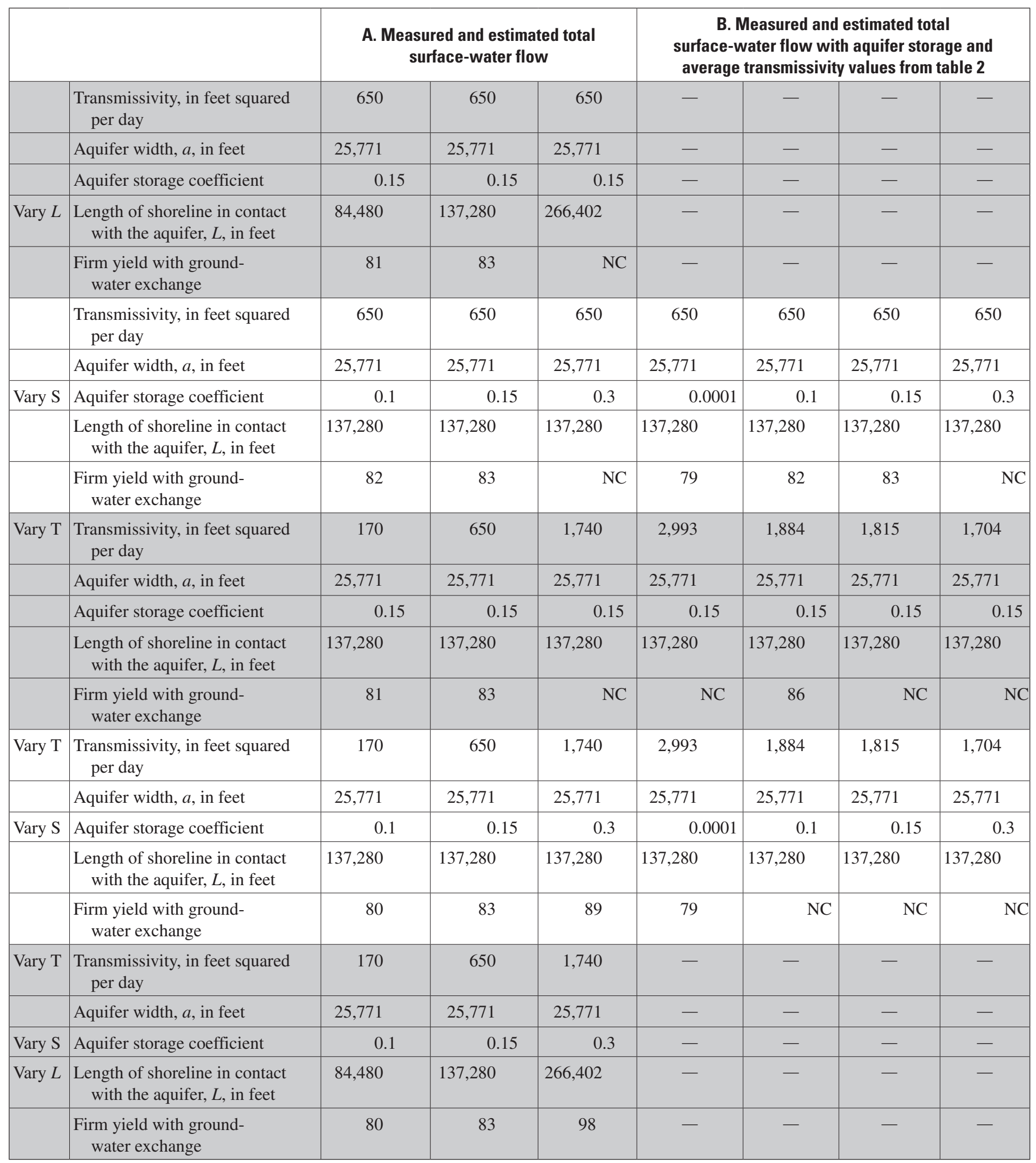


sensitivity ranges. This may indicate that those particular combinations of input parameters are not realistic (table 4A).

When the final sensitivity analysis (table 4B) was calculated using the best available estimates of $a$ (equals $25,771 \mathrm{ft}$ ), $L$ (equals 137,280 ft), $\mathrm{S}$ (equals 0.15), measured and estimated average surface-water flow $\left(202.9 \mathrm{ft}^{3} / \mathrm{s}\right)$, and a $\mathrm{T}$ range from 650 to $2,993 \mathrm{ft}^{2} / \mathrm{d}$ (the highest average $\mathrm{T}$ from table 2), average daily firm yield was again calculated at $83 \mathrm{Mgal} / \mathrm{d}$; however, the overall sensitivity range narrowed (from that shown in table $4 \mathrm{~A}$ ) to be 79 to $86 \mathrm{Mgal} / \mathrm{d}$ (table $4 \mathrm{~B}$ ).

Estimates of firm yield with no ground-water exchange were determined by varying total surface-water flow by plus or minus 25 percent. Firm yield with no ground-water exchange was $62 \mathrm{Mgal} / \mathrm{d}$ ( 22 percent lower) when surface-water flow decreased and $95 \mathrm{Mgal} / \mathrm{d}$ (20 percent higher) when surfacewater flow increased (table 3). The firm-yield estimator did converge on a solution when no ground-water exchange and varying total surface-water flow by plus or minus 25 percent were simulated; however, the results listed in the "Firm-Yield Estimator Methodology and Calibration" section of this report show that an increase or decrease of 25 percent in total surface-water flow into Converse Lake may not be realistic for this analysis. The average daily firm yield of $79 \mathrm{Mgal} / \mathrm{d}$ (table 3) is, therefore, a reasonable estimate for average daily firm yield with total surface-water flow to the reservoir because the best available estimate for total surface-water flow was used.

One additional point of uncertainty could be the value for total usable reservoir capacity. For example, if total usable reservoir capacity were reduced by about 65 percent, to $5,214 \mathrm{Mgal}$, as a result of sedimentation in the reservoir or by another cause, and if the associated relations of reservoir surface area to storage and reservoir stage to storage were correspondingly adjusted, average daily firm-yield results would change greatly, and the calibrated value for $\mathrm{T}$ would be $24,500 \mathrm{ft}^{2} / \mathrm{d}$. If the values listed above were used as input to the firm-yield estimator, average daily firm yield with groundwater exchange would be $99 \mathrm{Mgal} / \mathrm{d}$ with an uncertainty range of 77 to $132 \mathrm{Mgal} / \mathrm{d}$, and average daily firm yield using total surface-water flow to the reservoir without ground-water exchange would be $63 \mathrm{Mgal} / \mathrm{d}$ (with an uncertainty range of 52 to $74 \mathrm{Mgal} / \mathrm{d}$ ). These estimates of average daily firm yield would seem to be reasonable given the assumptions made about values of the input data to the firm-yield estimator. This example underscores the importance of accurate measured values for total usable reservoir capacity and the corresponding relations of reservoir surface area to storage and reservoir stage to storage. A study by Juracek (2006) indicated that decreases in reservoir water-storage capacity due to sedimentation ranged from less than 10 percent to 40 percent for certain reservoirs in Kansas. Results presented by Stricklin (2001) for Lake Tuscaloosa, Alabama, show that sedimentation in that lake is a dynamic process where maximum sediment deposition changes over time. When combining the results of the sensitivity test on total usable reservoir capacity described above, the age of the bathymetric data for Converse Lake, and results from other reservoir-sedimentation studies, use of the most accurate and up-to-date measured reservoir bathymetric data for the whole reservoir volume could substantially change the value of estimated firm yield for Converse Lake.

\section{Summary}

The estimate of average daily firm yield for a reservoir that is used for public supply can be used as an upper limit for withdrawals from the reservoir. Withdrawals from a reservoir that are equal to or less than the estimated firm yield ensure that the reservoir will meet these demands, assuming the reservoir continues to be affected by climatic and hydrologic conditions similar to those used in determining the estimated firm yield. As future demands for water supply increase, estimation of the firm yield provides an upper limit that can be compared to future demands to determine if the reservoir will be able to meet those additional demands in excess of current withdrawals. Alternatively, the firm yield can be compared to present reservoir withdrawals to determine if present withdrawals could be sustained through a drought (Archfield and Carlson, 2006). To assist officials of the Mobile Area Water and Sewer System in planning for future drinking-water demands in the service area, the average daily firm yield for Converse Lake was estimated by using two methods-(1) using total surfacewater flow to the reservoir without ground-water exchange and (2) using total surface-water flow to the reservoir with ground-water exchange and $\mathrm{T}$ and $\mathrm{S}$ values determined from model calibration.

The results presented in this report include a comprehensive estimation of firm yield values for Converse Lake that were dependent on the specific input parameters used. Although many variables were measured, some were estimated. Average daily firm yield estimated by the first method-using total surface-water flow to the reservoir without ground-water exchange-was $79 \mathrm{Mgal} / \mathrm{d}$, and firm yield estimated by the second method-using total surface-water flow to the reservoir with ground-water exchange and $\mathrm{T}$ and $\mathrm{S}$ values determined from model calibration-was $83 \mathrm{Mgal} / \mathrm{d}$. The difference in these firm-yield values indicates that groundwater interaction with Converse Lake may account for about 5 percent of the firm yield. However, aquifer properties that would describe more accurately this hydrologic interaction of the ground-water aquifer with the reservoir are not fully known.

When firm yield was estimated using total surfacewater flows without ground-water exchange ( $79 \mathrm{Mgal} / \mathrm{d}$ ), the result was about 8 percent lower than average withdrawals (85.60 Mgal/d) during 1994 through 1999 and about 25 percent greater than withdrawals $(59.37 \mathrm{Mgal} / \mathrm{d})$ during 2001 through 2006 - the periods before and after, respectively, the drought of 2000. The firm yield of $79 \mathrm{Mgal} / \mathrm{d}$ represents a conservative estimate because it does not include ground-water exchange with Converse Lake and the adjacent aquifer. 
Results of this study indicate that ground water can be a component of inflow to a reservoir in contact with a sand and gravel aquifer, but the degree to which it is important to Converse Lake is still uncertain. Also, following a drought, ground-water levels may take several years to recover to predrought levels. Given the role that ground-water exchange likely plays in the firm yield of Converse Lake, long-term monitoring of ground-water levels around the reservoir could provide useful information about the ground-water system surrounding Converse Lake. In addition, the firm-yield value may change substantially if, in future studies, up-to-date reservoir bathymetric data are used, as well as more accurate aquiferproperty values of transmissivity and storage estimated from field-measurement techniques rather than from the limited data available for this study, or if a detailed numerical ground-water flow model of the Converse Lake watershed is developed.

\section{References Cited}

Archfield, S.A., and Carlson, C.S., 2006, Ground-water contributions to reservoir storage and the effect on estimates of firm yield for reservoirs in Massachusetts: U.S. Geological Survey Scientific Investigations Report 2006-5045, 27 p.

Farnsworth, R.K., and Thompson, E.S., 1982, Mean monthly, seasonal, and annual pan evaporation for the United States: Washington, D.C., National Oceanic and Atmospheric Administration Technical Report NWS 34, 82 p.

Farnsworth, R.K., Thompson, E.S., and Peck, E.L., 1982, Evaporation atlas for the contiguous 48 United States: Washington, D.C., National Oceanic and Atmospheric Administration Technical Report NWS 33.

Gandl, L.A., 1979, The Oligocene aquifer system in Mississippi: U.S. Geological Survey Water-Resources Investigations Report 79-28, 1 pl.

Gandl, L.A., 1982, Characterization of aquifers designated as potential drinking-water sources in Mississippi: U.S. Geological Survey Open-File Report 81-550, 30 p.

Grubb, H.F., 1998, Summary of hydrology of the regional aquifer systems, South-Central United States: U.S. Geological Survey Professional Paper 1416-A, 61 p.

Heath, R.C., 1982, Basic ground-water hydrology: U.S. Geological Survey Water-Supply Paper 2220, 86 p.
Hirsch, R.M., 1982, A comparison of four streamflow record extension techniques: Water Resources Research, vol. 18, no. 4, p. 1081-1088.

Journey, C.A., and Gill, A.C., 2001, Assessment of waterquality conditions in the J.B. Converse Lake watershed, Mobile County, Alabama, 1990-1998: U.S. Geological Survey Water-Resources Investigations Report 01-4225, 131 p.

Juracek, K.E., 2006, Sedimentation in Kansas reservoirs [abs.], in Program of 23rd Annual Water and the Future of Kansas Conference, March 16, 2006, Topeka, Kansas: Manhattan, Kansas, Kansas State Research and Extention [unnumbered page].

Massachusetts Department of Environmental Protection, 1996, Estimating the firm yield of a surface-water reservoir-supply system in Massachusetts-A guidance document, Version 1.0: Massachusetts Department of Environmental Protection, Office of Watershed Management [variously paged].

National Oceanic and Atmospheric Administration, 2007, Record of climatological observations for Mobile Regional Airport station 015478: National Climatic Data Center; accessed online April 19, 2007, at http://cdo.ncdc.noaa.gov/ $d l y / D L Y$

Prudic, D.E., 1991, Estimates of hydraulic conductivity from aquifer-test analyses and specific-capacity data, Gulf Coast Regional Aquifer Systems, south-central United States: U.S. Geological Survey Water-Resources Investigations Report 90-4121, 38 p.

Renken, R.A., 1996, Hydrogeology of the southeastern Coastal Plain aquifer system in Mississippi, Alabama, Georgia, and South Carolina: U.S. Geological Survey Professional Paper 1410-B, 101 p.

Ries, K.G., III, and Friesz, P.J., 2000, Methods for estimating low-flow statistics for Massachusetts streams: U.S. Geological Survey Water-Resources Investigations Report 00-4135, 81 p.

Stricklin, V.E., 2001, Sedimentation profiles in Lake Tuscaloosa, Alabama, 2000: U.S. Geological Survey Open-File Report 01-317, 19 p.

Waldron, M.C., and Archfield, S.A., 2006, Factors affecting firm yield and the estimation of firm yield for selected streamflow-dominated drinking-water supply reservoirs in Massachusetts: U.S. Geological Survey Scientific Investigations Report 2006-5044, 39 p. 

Prepared by:

USGS Publishing Network

Raleigh Publishing Service Center

3916 Sunset Ridge Road

Raleigh, NC 27607

For additional information regarding this publication, contact: Carl S. Carlson, Hydrologist

USGS Massachusetts-Rhode Island Water Science Center 10 Bearfoot Road

Northborough, MA 01532

phone: $508-490-5047$

email: cscarlso@usgs.gov

Or visit the USGS Alabama Water Science Center website at: http://al.water.usgs.gov/ 


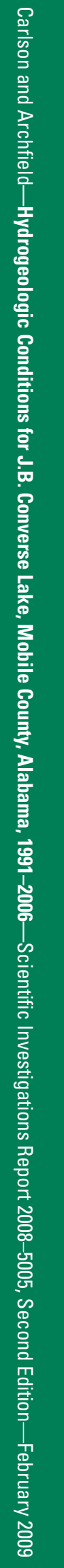

